\title{
APORTACIÓN AL ESTUDIO DE LA SEVILLA PRERROMANAY ROMANO-REPUBLICANA. REPERTORIOS CERÁMICOS Y SECUENCIA EDILICIA EN LA ESTRATIGRAFÍA DE LA CALLE ABADES 41-43
}

\section{CONTRIBUTION TO THE STUDY OF PRE-ROMAN AND REPUBLICAN ROMAN SEVILLA. POTTERY REPERTOIRES AND BUILDING SEQUENCE IN THE STRATIGRAPHY OF 41-43 ABADES STREET}

\author{
ÁLVARO JIMÉNEZ SANCHO* \\ ENRIQUE A. GARCÍA VARGAS** \\ FRANCISCO J. GARCÍA FERNÁNDEZ** \\ EDUARDO FERRER ALBELDA**
}

Resumen: Uno de los períodos de la historia urbana de Sevilla peor conocidos desde el punto de vista arqueológico es el que transcurre entre la consolidación urbana de la ciudad durante el siglo IV a.C. y el establecimiento colonial romano de mediados del siglo I a.C. Las recientes excavaciones (2002) llevadas a cabo en el edificio de la calle Abades 41-43, antigua sede de la Escuela Francesa de Sevilla, han ofrecido la oportunidad de avanzar en su conocimiento. En este trabajo analizamos el Corte 15A de dicha intervención, cuyos resultados permiten una primera aproximación a la evolución de la edilicia doméstica y de los conjuntos cerámicos en uso en el área nuclear del viejo oppidum turdetano. Ambos aspectos ilustran igualmente acerca de los ritmos y del carácter mismo del proceso de "Romanización" en Hispalis.

Palabras clave: Hispania, Hispalis, turdetanos, romanización, estratigrafía, cerámica.

Este trabajo se enmarca en una investigación más amplia cuya finalidad inmediata es el estudio arqueológico

\footnotetext{
* Arqueólogo

** Departamento de Prehistoria y Arqueología, Universidad de Sevilla. Proyecto Sociedad y paisaje. Análisis arqueológico del poblamiento rural en el sur de la Península Ibérica (siglos VIII a.C.-II d.C.), Ministerio de Educación y Ciencia (HUM-2005-07823).
}

Abstract: One of the worst-known periods of the urban History of Seville is the time passed between the reinforcement as a city of Seville during the IVth century B.D. and the roman settlement in the middle of the Ist. century B.D. The excavations made recently (2002) in the building situated in 41-43 of Abades st. had let us to advance in the knowledge of this period. In this work we analyze the 15A section, which results allow us to make an approximation to the evolution of domestic building as well as the sets of pottery used in the Turdetanian oppidum. Both aspects illustrate the rates and the features of the "Romanisation" in Hispalis.

Key words: Hispania, Hispalis, turdetani, romanisation, estratigraphy, ceramic.

del fenómeno urbano de la Sevilla prerromana y romana sobre bases empíricas más sólidas que las actuales. Tal objetivo requiere la revisión de las estratigrafías publicadas hasta la fecha y de los contextos cerámicos a ellas asociadas, trabajo que está en curso de realización en estos momentos pero que sería seguramente insuficiente si no viniera acompañado de la necesaria incorporación de datos procedentes de excavaciones urbanas recientes. 
El súbito incremento de la actividad constructiva pública y privada en Sevilla a partir de los años finales del siglo pasado ha ofrecido la oportunidad para ello. Esta dinamismo constructivo ha coincidido por fortuna con avances innegables en las técnicas arqueológicas de excavación y registro, también con un mejor grado de conocimiento de los repertorios cerámicos antiguos, lo cual ha supuesto para el arqueólogo no sólo un aumento notable en la cantidad de información disponible sino también, y sobre todo, una mejora sustancial de la "calidad científica" de la misma.

Las nuevas excavaciones y la revisión de las más antiguas a la luz de los avances en la investigación comienzan, pues, a arrojar luz sobre una de las fases peor conocidas de la arqueología sevillana, la que va desde la consolidación urbana de la ciudad en el siglo IV a.C. hasta la transformación que supuso la presencia de Roma en la región durante el siglo II a.C. Éste es un período para el cual la intervención realizada en el número 41-43 de la calle Abades en primavera de 2002 aporta datos del mayor interés que se refieren tanto a la evolución edilicia como a la de los conjuntos cerámicos de uso doméstico, lo cual creemos que justifica su presentación independiente.

La excavación llevada a cabo en los números 41-43 de la calle Abades se planteó inicialmente como una actuación de apoyo al proyecto de rehabilitación de un edificio histórico para transformarlo en un establecimiento hotelero. Al no existir proyecto de aparcamiento subterráneo, no estaba prevista en principio una afección importante al subsuelo del solar, pero su proximidad a los restos situados en la esquina Abades-Muñoz y Pabón, interpretados como infraestructuras de un edificio termal (Corzo 1991); la escasa afección del registro por alteraciones recientes, y la posibilidad de alcanzar los niveles arqueológicos más profundos, en una zona elevada de la ciudad donde no existe el condicionante impuesto a la actividad arqueológica por la proximidad del freático (Fig. 1), indujeron a la dirección facultativa a realizar una serie de sondeos que permitieran documentar la secuencia estratigráfica del solar hasta la máxima profundidad posible. La colaboración de los propietarios, que no estaban de ningún modo obligados a financiar la ampliación de la excavación, y mucho menos la profundidad de los sondeos, fue fundamental para el buen resultado de la misma. Creemos que esta actitud favorable al conocimiento en un mundo tan mercantilizado como el de hoy es digna al menos de nuestro agradecimiento.

A lo largo de la intervención se llevaron a cabo 20 catas en la estructura del inmueble con el fin de obtener información sobre su evolución edilicia. Al mismo

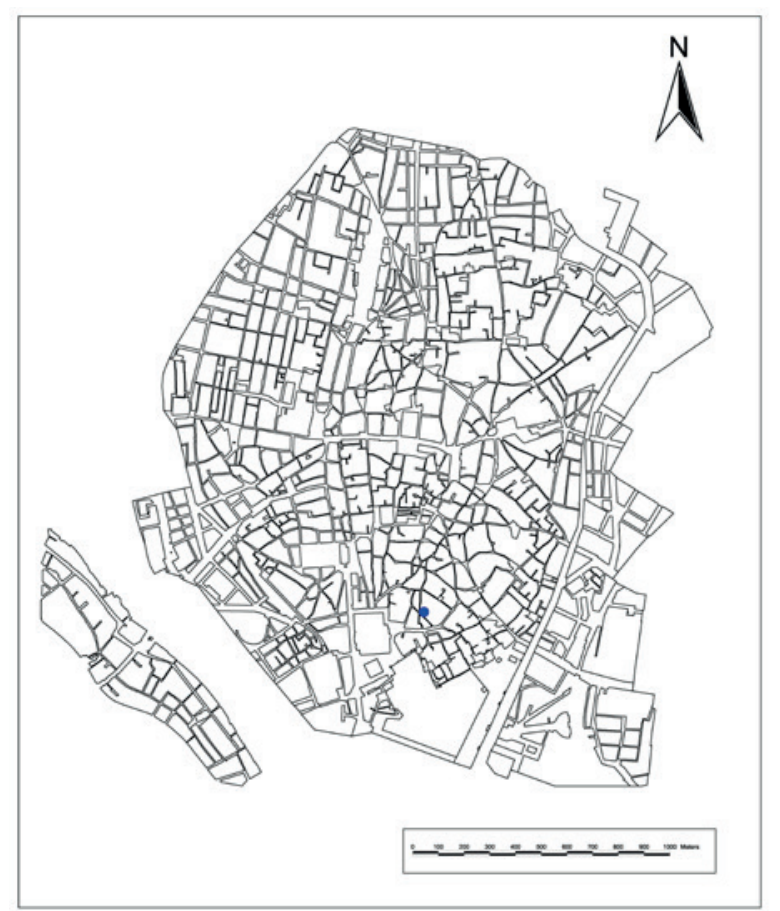

Fig. 1. Ubicación de la intervención en el casco urbano de Sevilla.

tiempo se plantearon dos sondeos estratigráficos en dos puntos extremos del edificio (15A y 18A), a los que habría que sumar los restos de una calzada de época romana, que apareció en una de las catas de control destinadas a estudiar las características de la cimentación (Fig. 2), y dos perforaciones geotécnicas, que permitieron obtener muestras sedimentológicas sobre el sustrato natural y los diferentes niveles de ocupación humana (Jiménez 2002: 127).

El Corte 18A fue ubicado en las proximidades de la calle Abades con el objeto de analizar el origen y evolución de esta vía (Fig. 2). Se planteó con unas dimensiones de 3,70 x 3,30 m. a una cota de 13,45 m.s.n.m. La profundidad máxima alcanzada fue tan sólo de $-5,00 \mathrm{~m}$. (8,45 m.s.n.m.), debido a la elevada cota del nivel freático en este sector y al riesgo de desestabilizar los muros del edificio. Se registraron tres fases constructivas, dos de las cuales corresponderían a viviendas de época romana (de mediados del siglo I a.C. a finales del I d.C.), mientras que la última ha sido identificada como un espacio abierto, una calle o plaza que debió funcionar entre los siglos XI y XIV, momento en que queda definida la calle Abades (Jiménez 2002: 142-146).

Por su parte el Corte 15A se localizó al fondo de la parcela, alejado del viario, con el fin de obtener una secuencia lo más amplia posible de la ocupación antrópica 


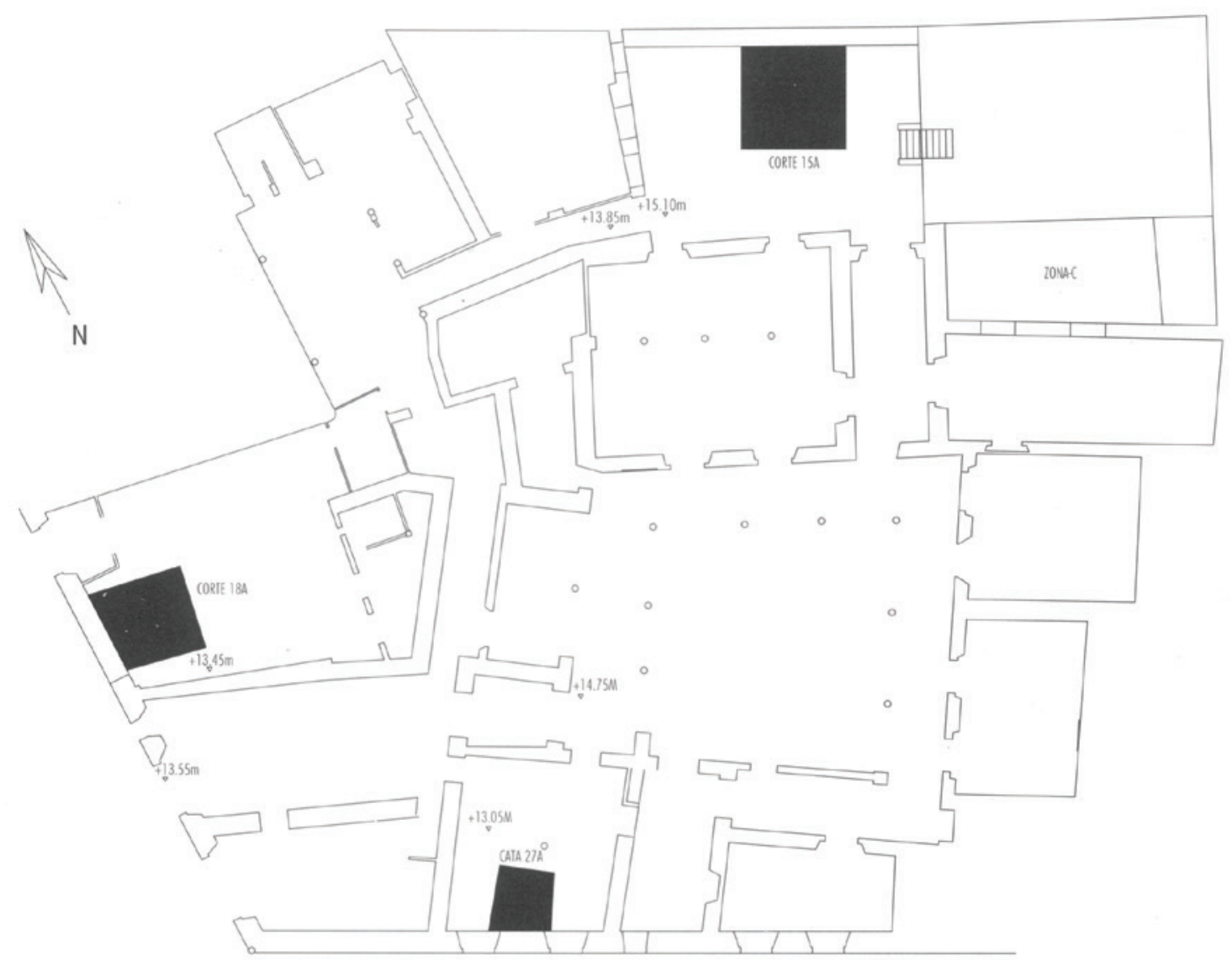

Fig. 2. Abades 41-43, ubicación de los cortes.

del solar (Fig. 2). Inicialmente el sondeo tenía unas dimensiones de 4 × $4 \mathrm{~m}$. a una cota de 15,10 m.s.n.m. Sin embargo, el área excavada fue reduciéndose paulatinamente debido a la aparición de estructuras constructivas de interés, quedando restringida a partir de la cota $-5,50 \mathrm{~m}$. a solamente $2,25 \mathrm{~m}^{2}$ de superficie. Se alcanzó, no obstante, una profundidad máxima de $-6,85 \mathrm{~m}$. $(8,25$ m.s.n.m.), sin que fuera posible agotar la estratigrafía debido a la incapacidad técnica de continuar la excavación en este punto. Pudieron documentarse hasta 8 fases constructivas, dibujando un arco cronológico que iría desde finales del siglo IV a.C. hasta el siglo IV d.C. momento en el cual se produce el abandono definitivo de la última domus romana (Jiménez 2002: 141).

Los resultados de estos sondeos ya se recogieron de manera sintética en un reciente artículo publicado por la revista Romula (Jiménez 2002). También se publicó un adelanto de los primeros niveles de ocupación y sus repertorios cerámicos en un estudio de conjunto sobre las secuencias estratigráficas de la Sevilla prerromana (García y González 2007). En esta ocasión nos ocuparemos específicamente de los contextos fechados entre los siglos IV y I a.C. que fueron documentados en el corte $15 \mathrm{~A}$.

\section{SECUENCIA ESTRATIGRÁFICAY Y CONTEXTOS DE OCUPACIÓN}

Los niveles de ocupación más antiguos registrados corresponden a un suelo compacto de arcilla roja muy limpia (UE 433), perteneciente posiblemente a una estancia cerrada cuyos límites desconocemos (Fig. 8). Este pavimento sella a su vez un nivel de relleno compuesto por tierra limo-arcillosa con nódulos de cal y restos cerámicos (UE 434), aunque ignoramos su potencia exacta ya que, como se ha visto, las limitaciones técnicas obligaron finalizar en este punto la excavación 


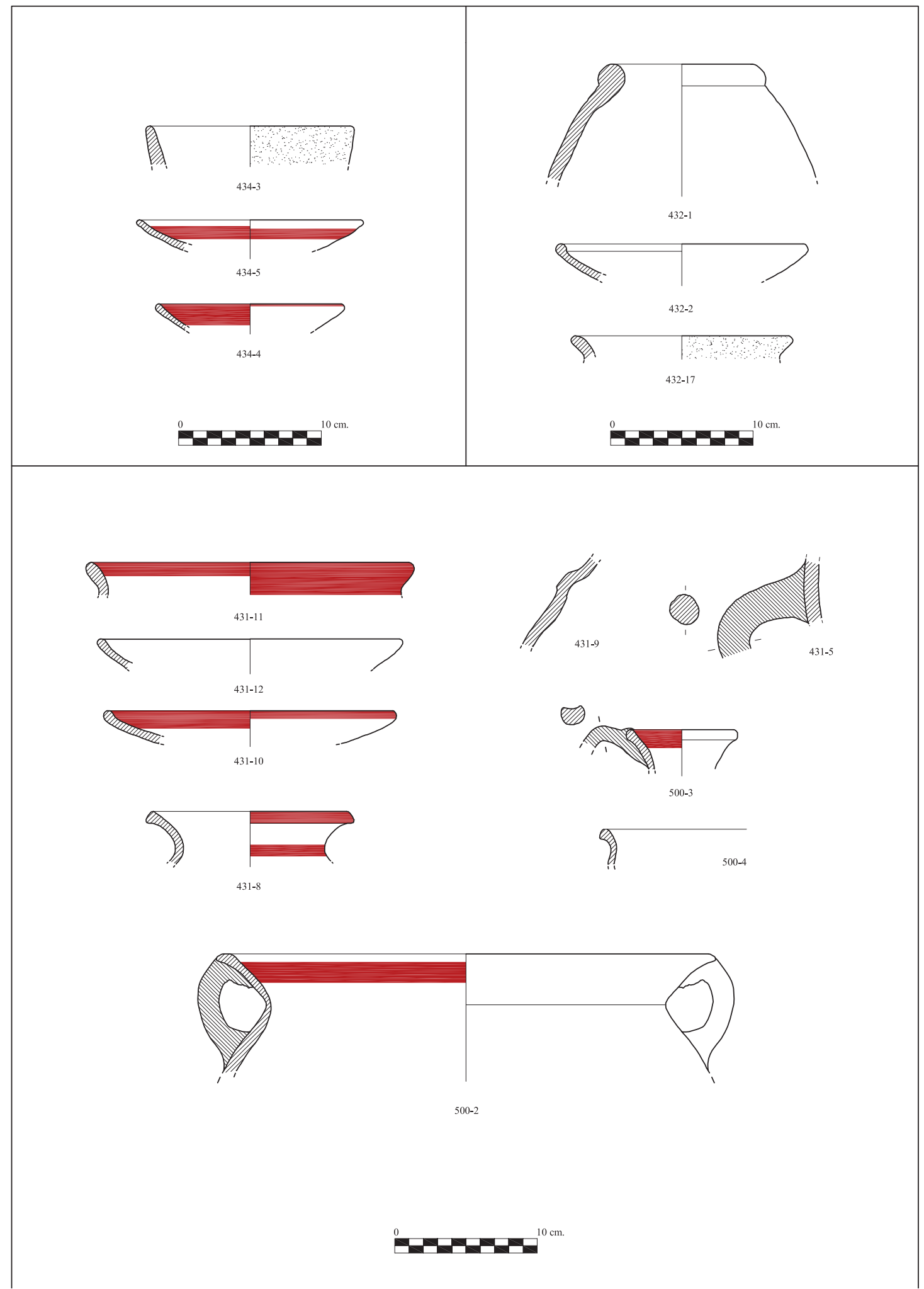

Lámina 1: UU.EE. 434, 432, 431 y 500 


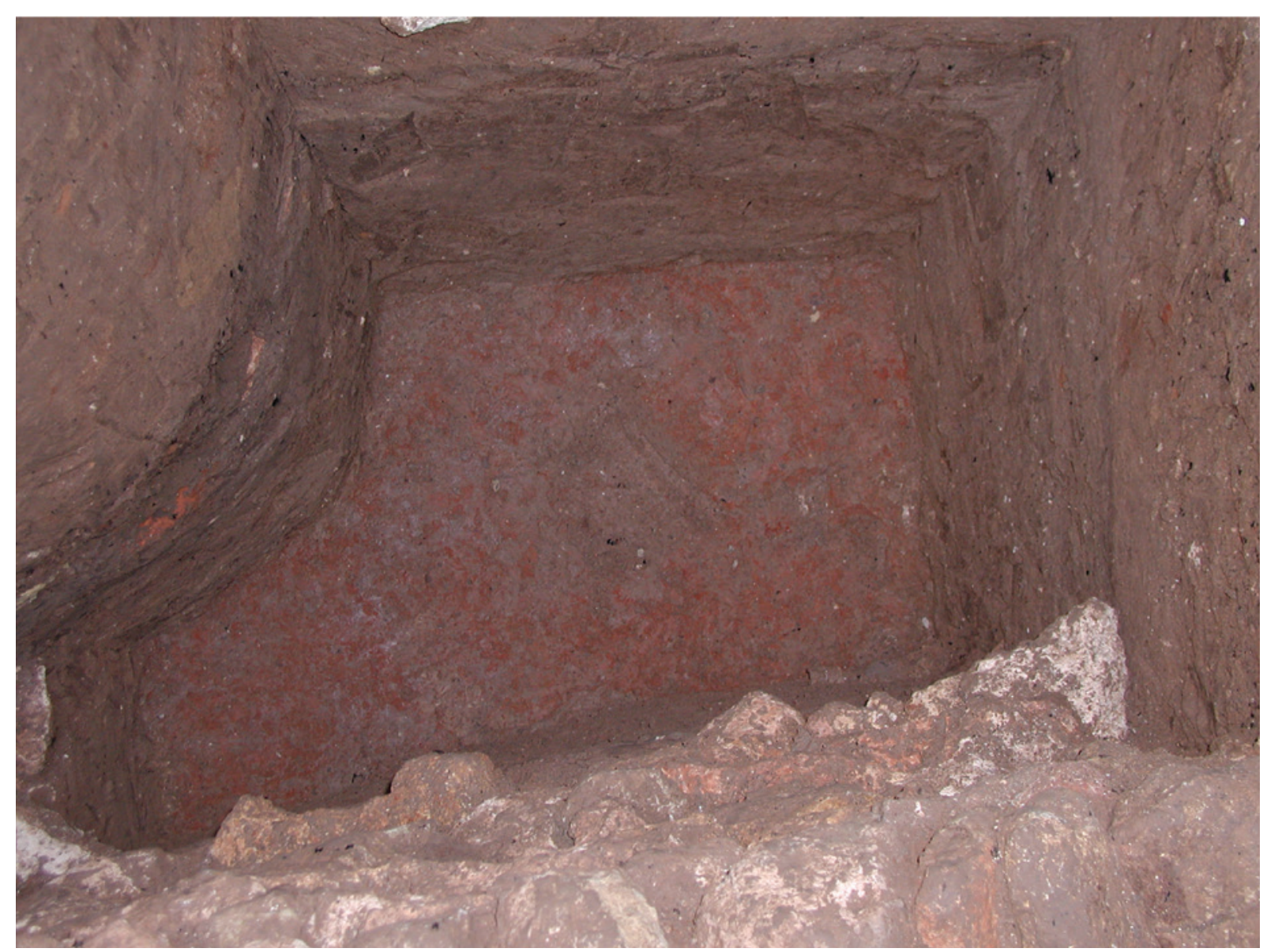

Fig. 3. Estructura 1.

sin que se agotara la estratigrafía. En él aparecen mezclados materiales de la II Edad del Hierro - principalmente cuencos de casquete esférico con decoración pintada a bandas - y cerámicas a mano de época orientalizante, entre las que predominan los tratamientos bruñidos y espatulados sobre las superficies groseras (Lám. 1). También se recogieron fragmentos atípicos de un gran recipiente modelado a torno y decorado con una banda ancha de color rojo que podría corresponder a un pithos. Poco más se puede decir sobre el contexto constructivo y funcional en el que se inscribe el pavimento, salvo que dada la evolución posterior de este sector podría interpretarse como parte de un ambiente doméstico (Jiménez 2002: 128).

Este nivel de ocupación se encuentra amortizado por un depósito limo-arcilloso de $58 \mathrm{~cm}$. de espesor (UE 432) que nivela y sirve de asiento a la siguiente estructura. Se piensa que pudo tratarse de un relleno intencionado realizado con los restos de alguna construcción cercana, ya que se advierten pellas de adobe y fragmentos de enlucido de cal mezclados con cerámica de distintas épocas: destaca un cuello de vaso "à chardon" realizado a mano, así como abundante cerámica a torno, entre la que únicamente pudimos identificar dos cuencos de casquete esférico con los labios ligeramente engrosados al interior, uno realizado en cerámica gris y otro común con la superficie bruñida en ambas caras (Lám. 1). La cronología de este nivel vendría dada por un borde perteneciente a una variante tardía del ánfora Mañá-Pascual A4 o T.12.1.1.1 de Ramón (1995: 238), cuya producción se inicia en la segunda mitad del siglo IV, aunque puede extenderse a lo largo del siglo III a.C. (Lám. 1: 432-1).

El segundo nivel de hábitat corresponde a la denominada "Fase constructiva 2. Restos de labores metalúrgicas. Siglo III a.C.” (Jiménez 2002: 129-131), a la que nos referiremos a partir de ahora como Estructura 1 (Fig. 3). Está formada por un murete de mampostería 
caliza y aparejo irregular con alzado de adobe (UE 430), al que se asocia un pavimento de arcilla y cal (UE 431). Reviste la dificultad de que ambas estructuras aparecieron embutidas en el perfil, lo que, unido a la reducida extensión del sondeo a esta profundidad, limita considerablemente las posibilidades de interpretación, así como su vinculación con la secuencia ocupacional. De hecho, ni siquiera queda claro que se trate de un muro, un banco o un elemento auxiliar, ya que sólo conservamos su cara interior, con una altura que apenas sobrepasa los $20 \mathrm{~cm}$. En cualquier caso, parece proyectar una orientación oblicua (SO-NE) con respecto al alineamiento predominante en las fases posteriores, con lo cual podríamos concluir que, una vez destruido este episodio, se inicia una nueva organización espacial distinta que evolucionará sin grandes cambios durante los siglos III y II a.C.

Adosada a esta estructura se documentó una pequeña fosa (UE 500) excavada en el propio pavimento, cuya superficie se encontraba endurecida y cristalizada por la acción del fuego. El relleno estaba formado por ceniza y tierra quemada, con algunos huesos de animales calcinados y escorias de bronce, lo que ha permitido interpretarla como un crisol de fundición. No obstante, si tenemos en cuenta sus dimensiones $(18 \mathrm{~cm}$. de diámetro y 10 de profundidad) y lo rudimentario de los restos, muy localizados en la zona excavada, podría tratarse más bien de una actividad metalúrgica de carácter doméstico (Jiménez 2002: 131). En su interior se recogieron también restos cerámicos, algunos de ellos con adherencias metálicas, aunque no parecen corresponder cronológicamente al nivel de uso de esta unidad (Lám. 1). Se trata de un recipiente de gran tamaño correspondiente a una variante tardía del pithos orientalizante, que podríamos situar, por sus semejanzas con los ejemplares hallados en Castillo de Doña Blanca, a partir de mediados del siglo VI a.C. (Ruiz Mata 1987: fig. 2-3), $\mathrm{y}$ un borde de urna globular con arranque de asa, muy similar al que adoptan a partir del siglo V a.C. las urnas tipo Cruz del Negro evolucionadas (Bandera y Ferrer 2002: fig. 10). Por su parte, el pavimento UE 431 ofrecía abundantes fragmentos de cerámica común a torno, mezclados con restos residuales de cerámica a mano y ánforas (Lám. 1). Junto a los habituales cuencos de casquete esférico sobresale un fragmento de urna con baquetón y un borde de urna globular, decorada esta última con dos bandas de color rojo vinoso en el cuello y en el labio (Lám. 1: 431-8). Se trata de formas que conviven sobre todo durante todo el siglo IV, aunque las urnas del segundo tipo aparecen ya con frecuencia en la centuria anterior, como podemos comprobar en los estratos X y XI de Vico (Bandera y Ferrer 2002: fig. 10).
La cancelación de la Estructura 1 corresponde a dos rellenos de nivelación sucesivos compuestos por desechos domésticos y escorias de hornos cerámicos (Fig. 8). El primero de ellos (UE 429) estaba formado por un depósito de tierra limo-arcillosa de aproximadamente 50 $\mathrm{cm}$. de espesor, con abundantes restos de carbón, huesos de animales y fragmentos cerámicos, así como pellas de adobe y enlucidos muy finos de cal. Aparecieron también restos de una tobera de arcilla parcialmente vitrificada, procedente probablemente de la misma actividad industrial documentada en el nivel anterior. Sobre este depósito se situaba un segundo relleno, mucho más delgado, formado por tierra arcillosa de color verdoso (UE 428). Se trata de un estrato de nivelación destinado a dar asiento a la siguiente fase constructiva, ya que en él descansaba directamente tanto el muro UE 424 como el pavimento UE 426. Presentaba asimismo abundantes restos de carbón y ceniza, pellas de barro cocido, algunos trozos de piedra caliza y guijarros de pequeño tamaño, restos de escoria y fragmentos cerámicos pasados de cocción, que podrían estar indicando la proximidad de algún horno cerámico.

La cerámica asociada a esta matriz es muy abundante, aunque poco elocuente desde el punto de vista cronológico. Está compuesta fundamentalmente por cuencos simples de casquete esférico con decoración pintada, lebrillos de cuello estrangulado sin decorar, urnas abiertas de gran tamaño, evolución de los vasos "à chardon" de época orientalizante, y un asa de ánfora, así como algunos fragmentos residuales de cerámica a mano (Lám. 2). Contamos también con un borde de urna globular y cuello estrangulado, forma heredera de las antiguas urnas tipo "Cruz del Negro", con los labios verticales y caídos en forma de pestaña (Lám. 2: 428-10). Como hemos visto, su presencia en los contextos del Bajo Guadalquivir no suele ir más allá de finales del siglo IV a.C. Un cuenco de gran tamaño y bordes entrantes, que podríamos incluir dentro de la forma I-H de Escacena, presenta grandes analogías con otro ejemplar procedente del nivel 9 de Cerro Macareno (Pellicer y otros 1983: fig. 34), de principios del III a.C. (Lám. 2: 428-26). Por último cabría destacar, por su singularidad, un cuenco lucerna de la variante no carenada con pie realzado y decorado al exterior con una banda ancha a la altura del borde y líneas paralelas de color rojo vinoso (Lám. 2: 429-12). A pesar de estas limitaciones cronológicas, se trata de un contexto bastante coherente cuyas concomitancias con los niveles 9 y 10 de Cerro Macareno (Pellicer y otros 1983: figs. 32-35) no dejan lugar a dudas de que nos encontramos a finales del siglo IV o, como mucho, a inicios del III a.C. 


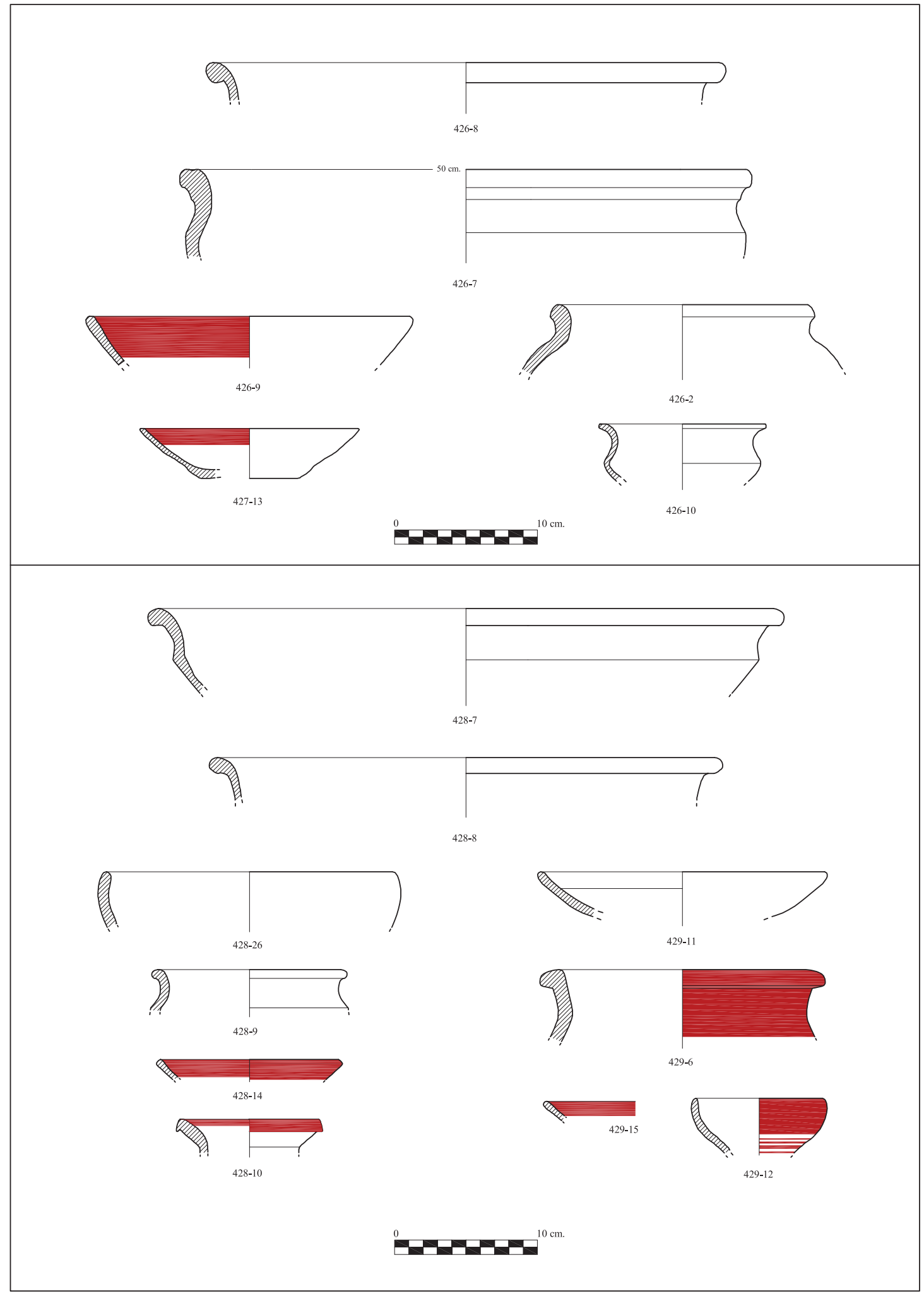

Lámina 2. UU.EE. 426, 427, 428 y 429. 


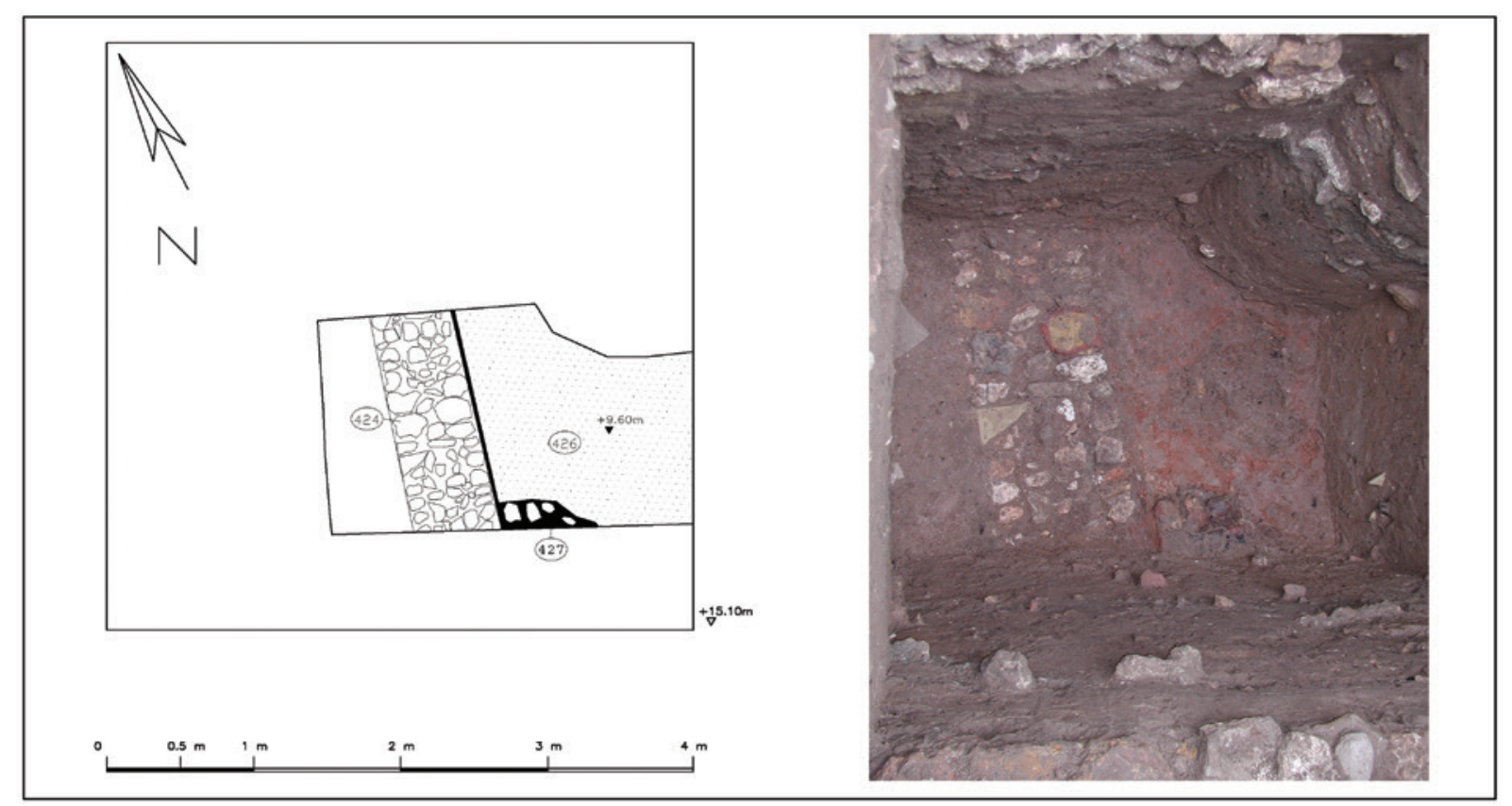

Fig. 4. Estructura 2.

La "Fase Estratigráfica 4. Vivienda I. Siglo III a.C.", que hemos denominado Estructura 2 (Fig. 4), está formada por un muro de aparejo irregular (UE 424) asociado a un pavimento de arcilla roja (UE 426). El muro, de $90 \mathrm{~cm}$. de altura y $55 \mathrm{~cm}$. de ancho, sigue una orientación SE-NO y asienta directamente sobre el nivel UE 429. De hecho, la ausencia de fosa de cimentación permite suponer que primero se construyó el muro y posteriormente se rellenó la zona con el depósito UE 428, sobre el que a continuación se situaría el suelo UE 426. El zócalo del muro es de mampostería careada, con lajas de piedra caliza y alcoriza unidas con un conglomerante de barro y carboncilla. Sobre la hilada superior se conserva un alzado de ladrillos de adobe de aproximadamente $20 \mathrm{~cm}$. de altura, cuyo arranque estaba también marcado por el contacto con el suelo UE 426. Éste se llevó a cabo mediante una moldura de media caña que revestía la parte inferior de dicho muro. El suelo UE 426, situado en su cara oriental, estaba constituido en realidad por una superposición de capas de arcilla roja, algunas enlucidas con cal, lo que revela un uso intenso y prolongado en el tiempo. Sobre este pavimento y adosado al muro 424 se documentó un hogar (UE 427), posiblemente doméstico, formado por una acumulación de guijarros y piedras alcorizas unidas con barro y revestido de adobe (Fig. 4). En su interior, mezclados con tierra, ceniza y carbón, se recogieron restos de un cuenco de casquete esférico, correspondiente a la forma I-C de Escacena, y un fragmento atípico de urna, ambos con decoración pintada (Lám. 2). Por su parte, en la cara oeste -que quedó sin excavar-se advirtió la existencia de otro pavimento de las mismas características que el UE 426, cuyo inicio podía apreciarse también en el contacto con el propio muro. En cuando a su función, tanto las características del suelo como la presencia del hogar permiten pensar en una estancia cubierta de ambiente doméstico. Asimismo, la potencia y calidad del zócalo de piedra podría estar indicando que se trata de un muro testero destinado a separar dos espacios interiores pavimentados (Jiménez 2002: 133).

Entre esta estructura y el depósito UE 428 hay un relleno arcilloso de entre 8 y $10 \mathrm{~cm}$. de espesor destinado a dar a siento al pavimento UE 426. En él se hallaron también restos heterogéneos de cerámica hecha a mano y cerámica a torno común o con decoración pintada (lebrillos y cuencos de casquete esférico, fundamentalmente), así como fragmentos atípicos de ánforas púnicas, que permiten datar su construcción a finales del siglo IV o inicios del III a.C. Destaca un borde de olla de factura grosera (Lám. 2: 426-2), similar a los 
documentados en el estrato XX de Vico (Bandera y Ferrer 2002: fig. 13), de mediados del siglo IV, y en el nivel 5 de Cerro Macareno, fechado a finales del siglo III a.C. (Pellicer y otros 1983: fig. 24). La misma cronología asignamos a un vasito para beber de la variante carenada (Lám. 2: 426-10), cuyos paralelos más antiguos se sitúan en los niveles 13 y 10 de Cerro Macareno, fechados respectivamente a principios y finales del siglo IV a.C. En conjunto, nos encontramos de nuevo ante un contexto que armoniza bien con los repertorios documentados en diferentes puntos del Bajo Guadalquivir a partir de finales del siglo IV a.C.

Con el abandono de la Estructura 2 se inicia un nuevo proceso deposicional en el que se suceden rellenos de colmatación y paquetes de nivelación destinados, respectivamente, a la subida de cotas y la preparación de los nuevos expedientes constructivos (Fig. 8). El primero (UE 422/423) constituye un depósito de tierra limo-arcillosa de $70 \mathrm{~cm}$. de espesor, con ceniza, carboncillo, abundante caliche y restos cerámicos. Se ha interpretado como el nivel de amortización de la ocupación anterior mediante la destrucción de las estructuras emergentes y su colmatación con los propios materiales eliminados y nuevos aportes de tierra y residuos domésticos (Jiménez 2002: 133). Las cerámicas asociadas a esta matriz proporcionan un conjunto bastante coherente de formas que conviven entre la segunda mitad del siglo IV y la primera mitad del III, lo que nos permite fechar la anulación de la Estructura 2 a finales del primero o durante el segundo cuarto de esta centuria (Láms. 3 y 4).

Destacan de nuevo, por su frecuencia, los cuencos de casquete esférico y los lebrillos de cuello estrangulado, en los que se continúa apreciando una tendencia generalizada a la simplificación de la decoración, que llega a desaparecer en la mayoría de los ejemplares, así como una mejora de las pastas, con cocciones oxidantes y engobes claros y homogéneos, que caracterizará ya a las producciones de los siglos III y II a.C. La única excepción correspondería a un espécimen decorado con una banda ancha de color rojo y un filete negro al interior, y con trazos paralelos de color oscuro a lo largo de la superficie del borde (Lám. 3: 423-34). Presenta, no obstante, similitudes con el ejemplar documentado en el nivel 4 de Cerro Macareno, que sus excavadores fechan a inicios del siglo II a.C. (Pellicer y otros 1983: fig. 23). La misma monotonía se observa en los cuencos de casquete esférico, aunque en este caso la aparición de algunos ejemplares de labios engrosados con decoración pintada, pertenecientes a las formas I-C y I-I de Escacena, podría situarnos entre los siglos IV y III a.C. Mención aparte merece un borde carenado de tendencia vertical y ligeramente apuntado (Lám. 3: 423-23), muy frecuente en los contextos tardopúnicos de la bahía de Cádiz (Sáez 2005: fig. 1, GDR 1.2.2).

El resto de la cerámica común estaría formado por un fragmento de urna con baquetón y decoración pintada bícroma (Lám. 3: 423-35), varios bordes de urnas de cuello acampanado y un cuenco-lucerna de la variante no carenada (Lám. 3: 423-24), que completan parcialmente el repertorio habitual de los siglos IV y III a.C. Por lo que respecta a la cerámica de cocina, se registran dos ollas de bordes engrosados (Lám. 3: 423-1 y 6), con paralelos en el estrato XX de Vico (Bandera y Ferrer 2002: fig. 13), de la segunda mitad del siglo IV a.C. Llama la atención el hallazgo de dos morteros de tradición púnica, uno de ellos decorado al interior con una banda ancha de color rojo (Lám. 3: 423-33), que encontramos presente en los niveles "turdetanos" del Castillo de Doña Blanca (Ruiz Mata 1987: fig. 4), así como en Cerro Macareno, al menos desde mediados del siglo IV a.C. (Pellicer y otros 1983: fig. 39). La cronología de este depósito estaría definida, sin embargo, por la presencia de dos ánforas de producción gaditana: un fragmento correspondiente al Tipo 8.1.1.2 de Ramón (1995: 222), destinada probablemente a la comercialización de productos agrícolas (Carretero 2005), y otro borde correspondiente al Tipo 8.2.2.1 (Ramón 1995: 225-226), cuya producción se generaliza, como sabemos, en el siglo III a.C. (Lám. 4: 422-52 y 53).

Sobre este estrato se sitúa un relleno de tierra arcillosa de color grisáceo con ceniza, carboncillo, trozos de piedra, caliche y restos cerámicos (UE 420). Tiene un espesor máximo de $35 \mathrm{~cm}$. y es uniforme por todo el corte, aunque buza hacia la esquina suroeste (Fig. 8). Se interpreta como parte de la misma operación de anulación y aterrazamiento que sella la Estructura 2. En este caso la cerámica, mucho menos expresiva, está representada por varios cuencos de perfiles similares a los hallados en la unidad anterior, un cuenco lucerna de la variante no carenada, urnas globulares o bitroncocónicas y urnas con baquetón, decoradas con anchas bandas rojas (Lám. 4). Un vaso de cuello estrangulado y tendencia ovoide (Lám. 4: 420-9) guarda similitudes con el ejemplar hallado en el nivel 7-8 de Cerro Macareno, fechado en el segundo tercio del siglo III a.C. (Pellicer y otros 1983: fig. 30). Podría tratarse de un espécimen relacionado con la forma XV de Escacena, cuya difusión por el Bajo Guadalquivir se inicia precisamente en este momento (Escacena 1987: 525-526), si bien el estado fragmentario de nuestro ejemplar no permite una adscripción segura.

El siguiente nivel de ocupación -"Fase constructiva 4. Vivienda II. Siglo III a.C.” (Jiménez 2002: 133-134)corresponde a nuestra Estructura 3 y está formado por 


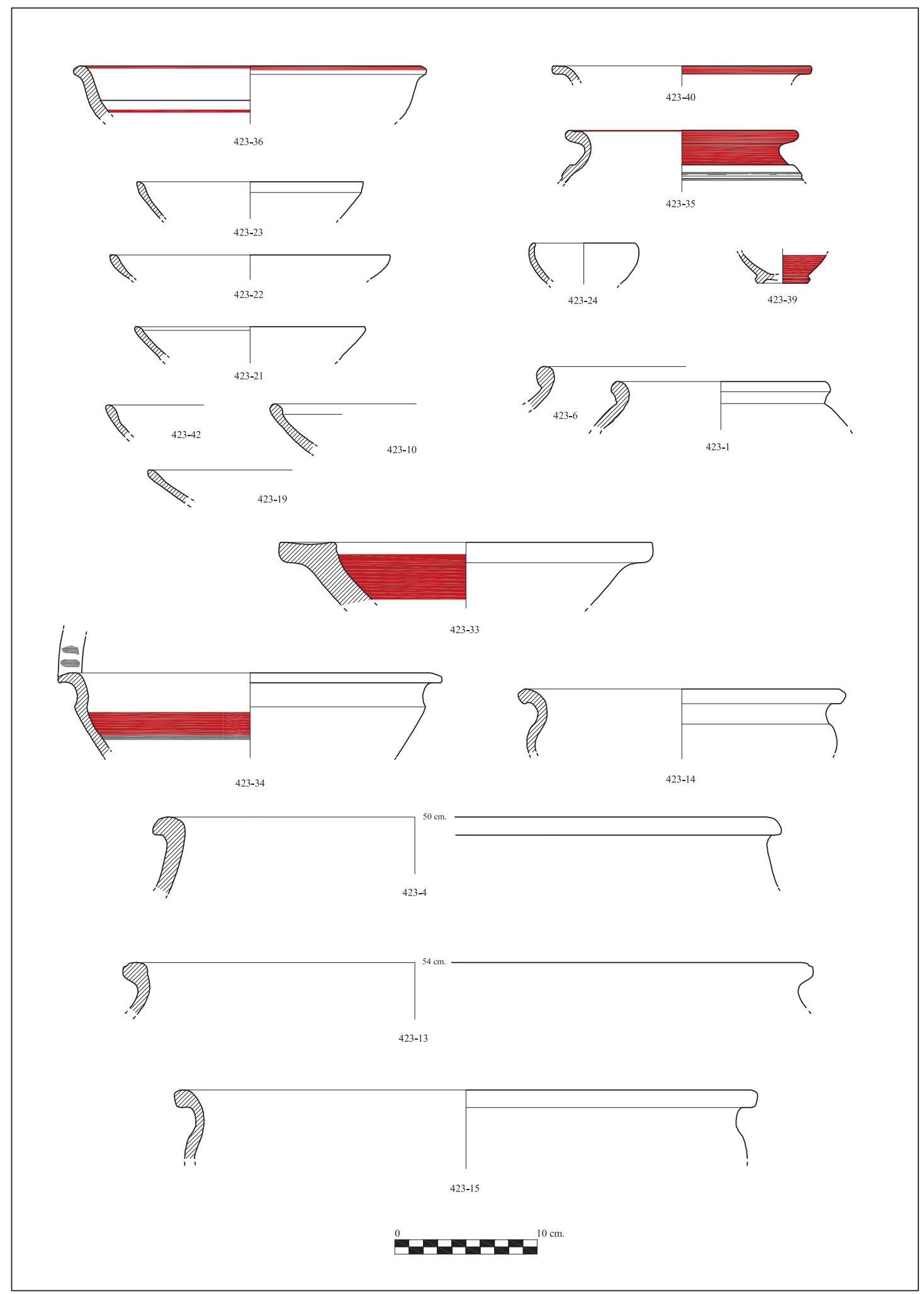

Lámina 3. UE 423. 


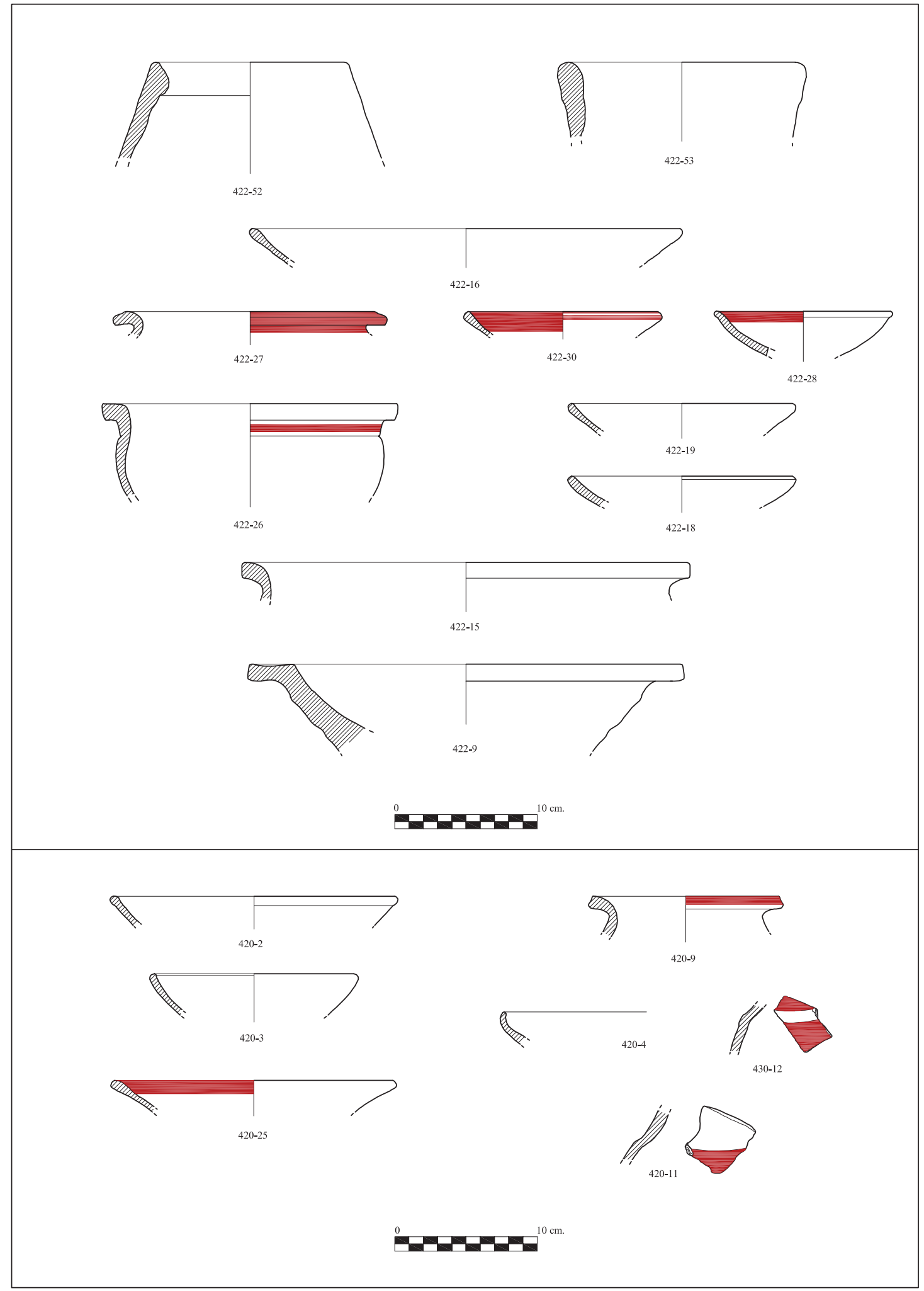

Lámina 4. UU.EE. 422 y 420. 
un muro muy deteriorado de guijarros y mampostería caliza careada, unidos con barro y ceniza (UE 418). Carece de suelo asociado, lo que pudo deberse a la propia dinámica destructiva relacionada con el expediente de anulación y construcción del nivel posterior. El muro, del que sólo se conserva una hilada de piedras y un alzado de adobe de apenas $10 \mathrm{~cm}$. de altura, mantiene la misma orientación SE-NO, lo que podría estar indicando una continuidad en la secuencia ocupacional. La cimentación se realiza sobre un estrato de nivelación (UE 419) formado por un depósito arcilloso con carboncillo, caliche y restos de adobe de $23 \mathrm{~cm}$. de espesor, al que corta ligeramente. En su interior aparecieron restos de un lebrillo de grandes dimensiones provisto de asas y un cuenco correspondiente a la forma I-C de Escacena, cuya producción podríamos situar entre los siglos IV y II a.C. (Lám. 5). No obstante, la cronología de este nivel de ocupación vendría dada por un mortero de perfil evolucionado (Lám. 5: 419-3), asimilable al tipo GRD 3.1.1 de Cádiz (Sánz 2005: 152) y con paralelos claros en la última fase de Montemolín (García Vargas y otros 1989: fig. 3) y en el nivel 6 de Cerro Macareno (Pellicer y otros 1983: fig. 27, 1824), de mediados del siglo III a.C.

La amortización de la Estructura 3 (Fig. 8) se lleva a cabo mediante un depósito de tierra arcillosa de 15 $\mathrm{cm}$. de espesor con abundante caliche y residuos domésticos (UE 417). Es probable que los materiales asociados al muro UE 418 procedan de este mismo depósito (Lám. 5), ya que ambos conforman conjuntos muy heterogéneos en los que se entremezclan restos de otras épocas (cerámica a mano, cerámica gris orientalizante, ánforas, etc.) con especies propias del siglo III, como puede ser el caso de un fragmento atípico de cerámica tipo "Kuass". Destacan formas que se generalizan a partir de mediados o finales del siglo IV, como los vasos para beber (Lám. 5: 418-7 y 417-1), las ollas de cocina de factura tosca (Lám. 5: 418-25 y 27), similares también a las documentadas en el estrato XX de Vico, o las urnas globulares con asas acanaladas a la altura de la panza (Lám. 5: 417-18), correspondientes a la forma IX-A de Escacena. Estas últimas se encuentran ya presentes en el Cerro Macareno desde el nivel 10, de finales del siglo IV a.C. (Pellicer y otros 1983: fig. 35), aunque su producción se extiende a partir de la siguiente centuria (Escacena 1987: 403). Un ánfora de tradición local, asimilable a la forma B-C de Pellicer (Lám. 5: 418-19), cuenta también con paralelos en Cerro Macareno desde finales del siglo IV a.C. (Pellicer 1978: fig. 4, 1576). Entre los cuencos, que pueden agruparse en conjunto dentro de las formas I-B y I-D de Escacena, hemos identificado un ejemplar con el borde biselado al interior y al exterior (Lám. 5: 41738), lo que representa un rasgo característico del siglo III, como ha podido observarse, sobre todo, en los últimos niveles de Montemolín (García Vargas y otros 1989: 224) y en Vico (Bandera y Ferrer 2002: fig. 13). Las formas más comunes continúan siendo los lebrillos de cuello estrangulado, predominando los especimenes sin decoración. Destacan algunos ejemplares de perfil más evolucionado, con el borde engrosado de sección oval o almendrada, que comienzan a ser frecuentes a finales del siglo III a.C. (Lám. 5: 418-1). Por otro lado, se documentan también fragmentos de urnas globulares o bitroncocónicas de cuello acampanado. Se trata, como hemos visto, de formas muy comunes que perduran hasta bien entrada la dominación romana. En resumen, tanto la posición estratigráfica de este nivel, anterior a la llegada de las primeras importaciones itálicas, como los propios repertorios cerámicos, que encajan bien con los contextos generales que documentamos en el Bajo Guadalquivir durante la segunda mitad del siglo III, permiten situar la anulación de la Estructura 3 en las últimas décadas de esta centuria.

Encima de este nivel aparecieron otros dos rellenos de amortización: UE 412/415 y UE 411, constituidos en ambos casos por una matriz arcillosa de 20 a $25 \mathrm{~cm}$. de espesor con restos de caliche y adobe. Sobre ellos asientan directamente las estructuras correspondientes al siguiente nivel de ocupación: el muro UE 381 y el pavimento UE 382. Los materiales documentados en la UE 412/415 son muy similares a los aportados por el depósito UE 417 (Lám. 6): cuencos de casquete esférico, urnas de cuello acampanado, lebrillos y ollas de cocina de factura tosca, mezclados con fragmentos atípicos de cerámica a mano procedentes de la destrucción de los niveles anteriores. Destaca la presencia de un borde de ánfora perteneciente al Tipo 8.1.1.2 de Ramón (Lám. 6: 412-3), de cronología algo anterior (Ramón 1995: 222), y un asa adscribible probablemente a otro ejemplar del tipo 8.2.1.1 (Ramón 1995: 225-226), cuya producción efectivamente llega a finales del siglo III (Muñoz 1987: 474), adentrándose en las primeras décadas del II a.C. (Sáez y otros 2004: 123).

La "Fase constructiva 5. Vivienda III. Segunda mitad del S. III a.C." (Jiménez 2002: 134-135), que nosotros denominamos Estructura 4 (Fig. 5), mantiene la misma orientación que las anteriores y está formada por dos muros trabados en ángulo recto (UE 381 y UE 405), el primero de los cuales servía de separación entre dos espacios interiores pavimentados con suelos de arcilla roja (UE 382 y UE 410). El muro de cierre de ambas estancias (UE 405) está realizado con aparejo irregular de mampostería caliza con guijarros, lajas de 


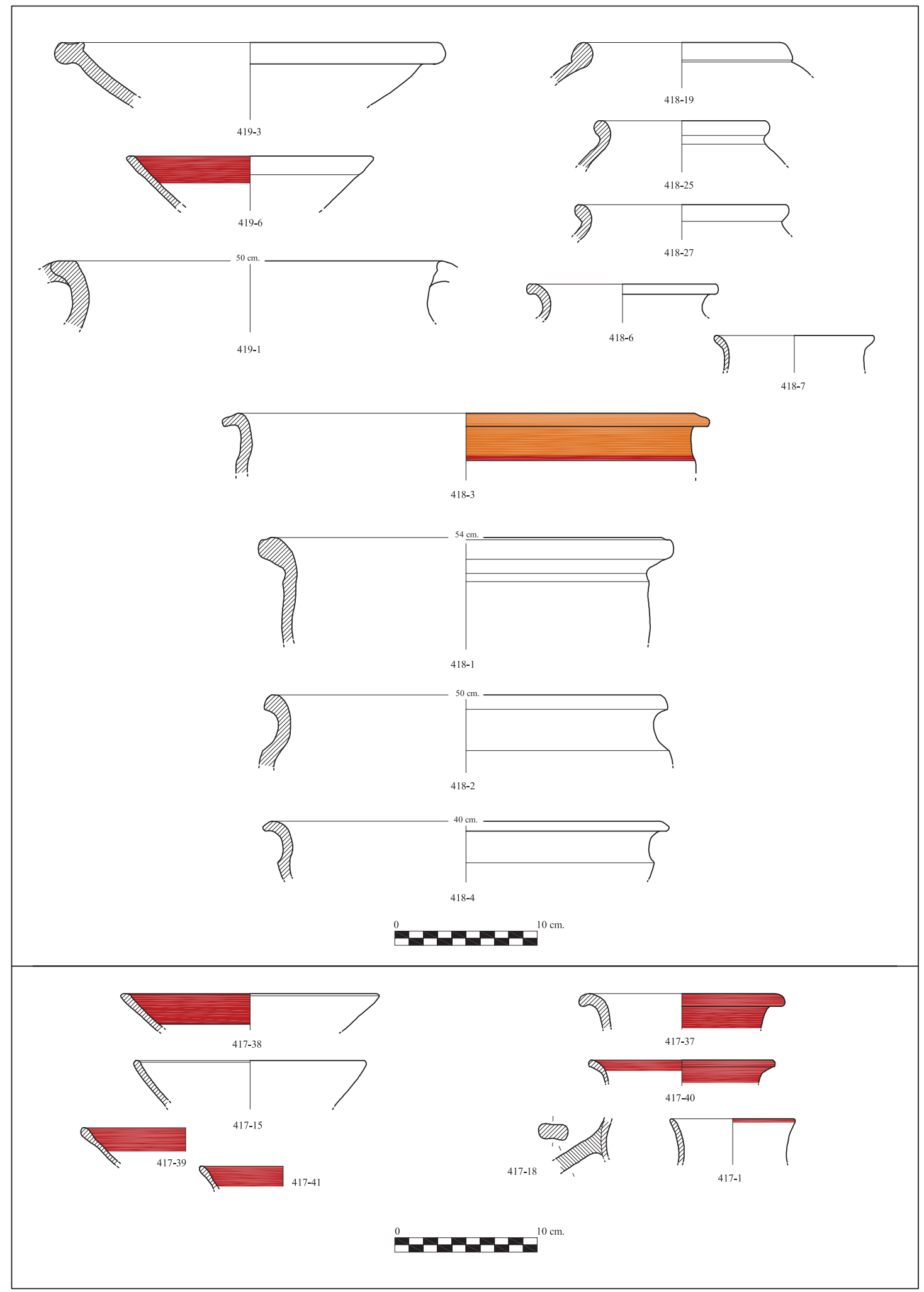

Lámina 5. UU.EE. 419, 418, y 417. 


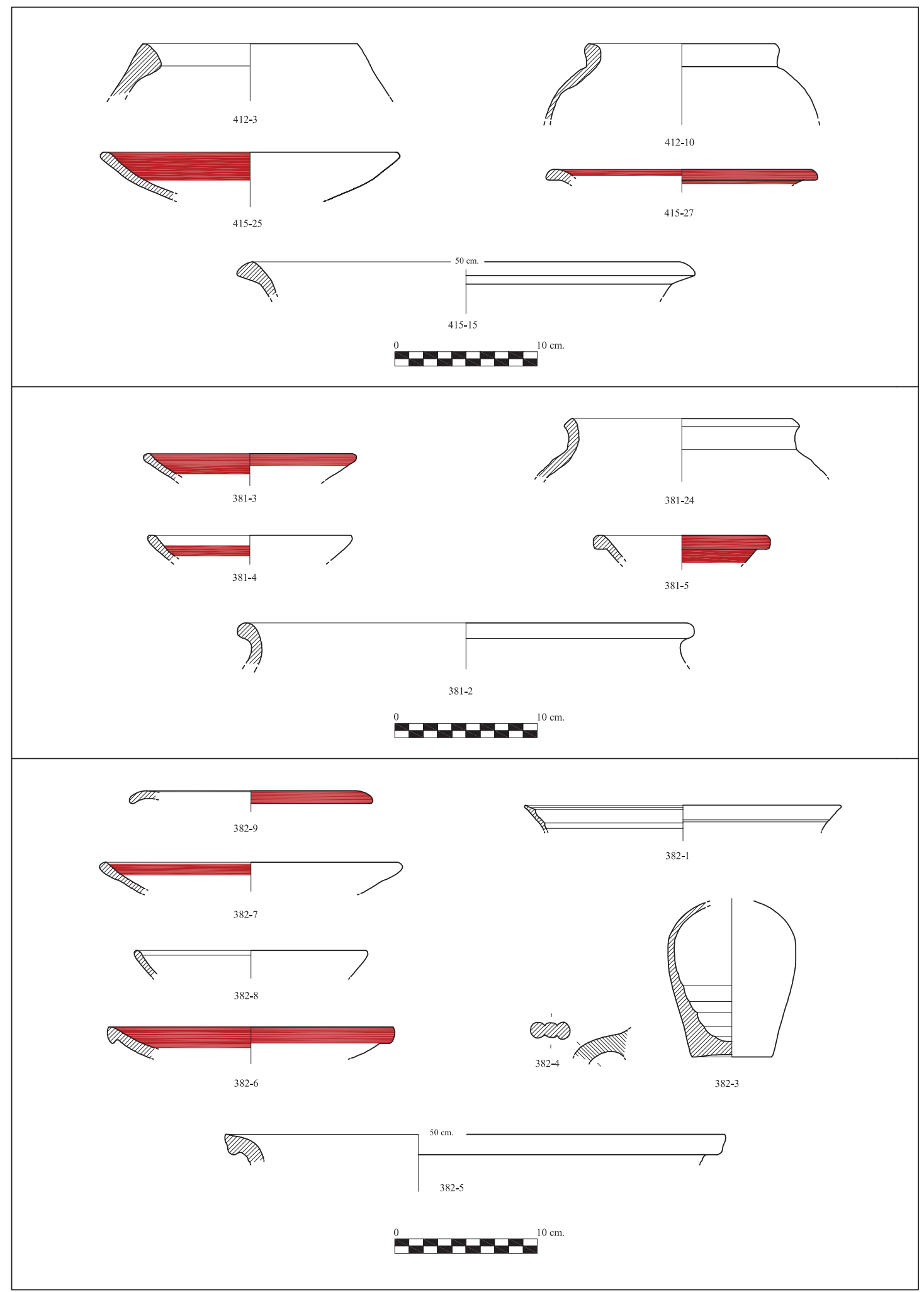

Lámina 6.: UU.EE. 412, 415, 381 y 382 


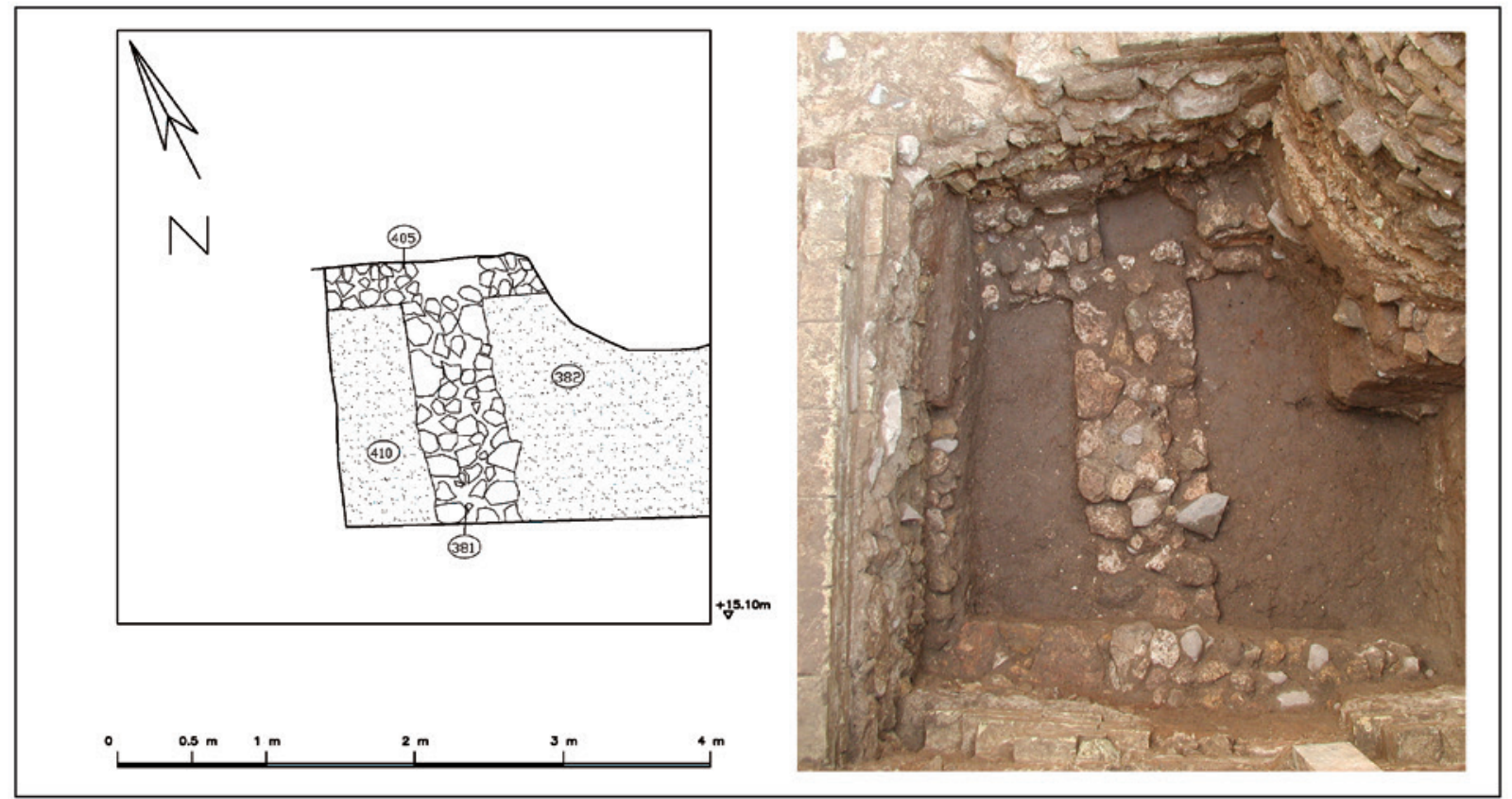

Fig. 5. Estructura 4.

pizarra y barro. Sólo se documentan $35 \mathrm{~cm}$. de anchura y $50 \mathrm{~cm}$. de altura máxima, quedando el resto empotrado en el perfil. Por su parte, el muro interior (UE 381) presenta únicamente una sola hilada de los mismos materiales, con una anchura de $54 \mathrm{~cm}$. y una longitud de poco más de medio metro. Al perfilar el lado sur del corte se pudo comprobar que el muro no continuaba pero sí el suelo, lo que podría sugerir la existencia en este punto de un vano o una puerta. Ambos pavimentos (UE 382 y UE 410) conforman en realidad una única capa de arcilla roja tostada de $5 \mathrm{~cm}$. de espesor mezclada con ceniza y carboncilla. El material asociado es poco expresivo y está compuesto básicamente por fragmentos atípicos cerámica común o con decoración pintada (Lám. 6). Las únicas formas destacables desde el punto de vista cronológico son un borde de lebrillo de perfil evolucionado (Lám. 6: 382-5), similar a otro procedente del nivel 4 de Cerro Macareno, de inicios del siglo II a.C. (Pellicer y otros 1983: fig. 23, 1994); un plato de borde vuelto y engrosado decorado con una capa de engobe rojo al interior (Lám. 6: 382-6); y un borde de plato de cerámica campaniense (Lám. 6: 382-1), correspondiente a la forma M.2154, que permite fechar la ocupación de este nivel a finales del siglo III o inicios del II a.C.

La "Fase constructiva 6. Vivienda IV. Fines del siglo II a.C. Primer tercio del siglo I a.C.”, considerada aquí Estructura 5 (Fig. 6), representa un nuevo episodio estratigráfico que esta vez viene acompañado de un notable cambio en la composición del repertorio cerámico a él asociado.

Si bien los muros de esta estructura no montan directamente sobre los de la anterior, la continuidad entre ambas fases constructivas viene sugerida por la perduración de las orientaciones y de la edilicia de los paramentos. La excavación permitió documentar dos muros (UE 373 y UE 404) que trababan en ángulo recto y cuya cimentación había sido realizada con una hilada de pequeñas piedras de roca alcoriza y guijarros, todo ello trabado con barro. El alzado de ambos paramentos se levantó en tapial. Del muro sur, que presenta un vano en su extremo oriental, se ha documentado un recorrido de $2 \mathrm{~m}$. de largo, mientras que del situado al este se excavó una longitud total de $2,10 \mathrm{~m}$. La anchura de los paramentos oscilaba entre 25 y $30 \mathrm{~cm}$.

El espacio delimitado por los muros 373 y 404 fue sucesivamente pavimentado con dos suelos superpuestos de los cuales el más antiguo (UE 406) sólo se conservaba intacto en un pequeño sector de $36 \times 6 \mathrm{~cm}$. Se trataba de una torta de cal enlucida en rojo en su cara superior, cuya posición estratigráfica sobre la UE 372 (infra), nivel de amortización de la casa anterior (Estructura 4), y cuya conexión con los muros de la nueva vivienda (UE 373-404) la identifican como primera 
pavimentación de ésta. El suelo de cal UE 406 fue sustituido posteriormente por otro de mayor entidad constructiva (Fig. 6): un encachado (UE 371) de fragmentos cerámicos alternado en algunos sectores con losas calizas irregulares de 40-45 cm. de diámetro medio (UE 403). Sus características físicas son las propias de la pavimentación de un patio o estancia abierta. El pavimento UE 371-403 fue finalmente anulado por los niveles de construcción (UE 363-370 y UE 369) de la “vivienda altoimperial" o Estructura 6 (Fig. 7).

Los materiales cerámicos extraídos de la fábrica de los muros de la Estructura 5 y de los restos del pavimento UE 406 son escasos y poco significativos. Las únicas unidades estratigráficas que proporcionaron elementos de juicio para el establecimiento de la cronología de construcción de esta estructura son las correspondientes a la amortización de la anterior, pues el proceso constructivo de cada uno de los niveles de habitación documentados en el corte 15A de Abades se inicia, como se ha señalado, con la demolición y nivelación de las estructuras precedentes. Las unidades directamente relacionadas con el episodio de anulación de la Estructura 4 son las UU.EE. 380, 409 y 372, siendo ésta última un vertido homogéneo sobre el que descansaba directamente el primer pavimento de la "vivienda republicana".

Entre los fragmentos cerámicos con morfología diagnosticable de las unidades consideradas destacan los de importación itálica. Se trata sobre todo de cerámicas asignables al tipo A de las producciones campanas (Lám. 7). Se documentan las formas Lamb 6, Lamb. 28 a-b (Lám. 7: 372-4), Lamb 31b (Lám. 7: 372-5 y 7), Lamb. 33b (Lám. 7: 372-3 y 14), Lamb. 36 (Lám. 7: 372-1) y M. 3131 (Lám. 7: 372-6), un repertorio característicos de la fase media de producción, dentro de las cuales el vaso carenado del tipo Lamb. 28 a-b y el gobelete M. 3131 constituyen los elementos más antiguos, pues su producción concluye hacia mediados del siglo II a.C. Ninguna de las dos se encuentra ya en el pecio de Punta Scaletta, fechado hacia los años 140-130 a.C. (Lamboglia 1964), aunque la presencia de una u otra de estas formas en contextos peninsulares datados entre 150 y 130 parece abogar por una perduración de su circulación en Hispania hasta principios del último tercio de esta centuria (Marín Jordá y Ribera 2000; Principal 2000). Para el resto de las formas citadas, se constata la continuidad de su producción en A media hasta fines del siglo II, con las mismas características tipológicas. Todas ellas pasan a formar parte, también sin grandes variaciones formales, del repertorio de la variante tardía (100-50/40 a.C.) de la campaniense A.

Al conjunto de campanienses procedente de los niveles de construcción de la Estructura 5 debe unirse un fondo de cubilete de paredes finas de la forma Mayet I-Ricci 1/1 hallado en la UE 372, cuya cronología es coherente con la que ofrecen las importaciones campanas (Lám. 7: 372-16). El resto de las cerámicas documentadas en la unidad corresponde a la tradición artesanal turdetana (Lám. 7). Se trata mayoritariamente de urnas y cuencos de difícil adscripción cronológica. Menos problemas para una propuesta de datación presentan otros recipientes cerámicos, como dos pequeños vasos de perfil en S (Lám. 7: 372-28 y 380-1), un fragmento atípico de urna con baquetón, un plato común de pequeño tamaño (Lám. 7: 380-20) y un cuenco de bordes entrantes, asimilable a la forma I-H de Escacena, con un tratamiento de barniz rojo al interior y al exterior y una decoración poco habitual a base de puntos a lo largo del borde (Lám. 7: 380-21). Encontramos también un borde de ánfora Pellicer D (Lám. 7: 380-3), correspondiente a la variante 2 de Niveau (Niveau 2002: 238-239), y un segundo borde ya indiferenciado -variante 6 de Niveau- (Lám. 7: 372-37), cuya morfología es coherente con la tipología de estos contenedores en la segunda mitad del siglo II a.C.

Los rellenos relacionados con la construcción del pavimento UE 371-403 ofrecen, por su parte, materiales cerámicos lo suficientemente significativos para proponer una datación post quam de la reforma de la Estructura 5. El encachado UE 371 está constituido por un número importante de fragmentos cerámicos cuyo encuadre cronológico debe situarse en torno al último cuarto del siglo II a.C. Esta datación es proporcionada de nuevo por la cerámica campaniense (A y B), a la que hay que unir ahora las ánforas vinarias del tipo Dressel 1A (Lám. 9). El repertorio de formas de barniz negro campano procedente de esta unidad es poco expresivo a efectos cronológicos, limitándose en lo que respecta a las producciones del tipo A a las formas Lamb 8b (lám. 9: 371-15), Lamb. 27 a-b (Lám. 9: 371-23), Lamb 33b (Lám. 9: 371-72) y Lamb. 36. Las tres últimas son comunes a la campaniense A media y a la tardía, mientras que la forma $8 \mathrm{~b}$ resulta más frecuente en los conjuntos tardíos, aunque tiene su origen en los últimos momentos (último cuarto del siglo II a.C.) de la producción de la variante media.

Éste es probablemente el momento en que deban fecharse estas cerámicas, si atendemos a la escasa presencia de vasos en campaniense B de Cales, cuya recepción mayoritaria en el sur de Hispania se documenta a partir de principios del siglo I a.C. (Adroher y López 2000: 152). Estos últimos están representados por un fondo asignable a la forma Lamb. 1 (Lám. 9: 371-40), que aparece en el repetorio de las campanienses calenas a partir de la fase media de la producción 


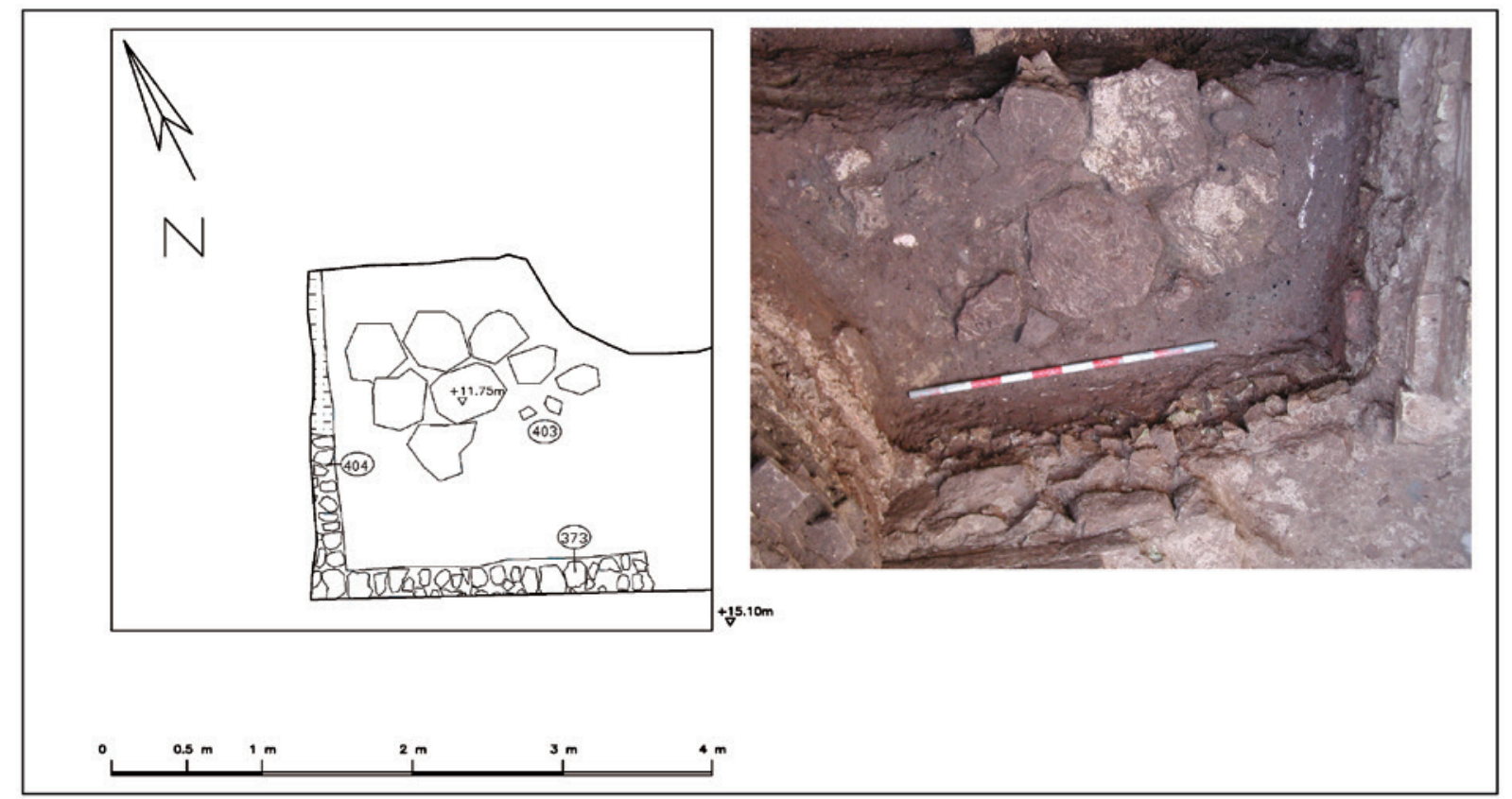

Fig. 6. Estructura 5.

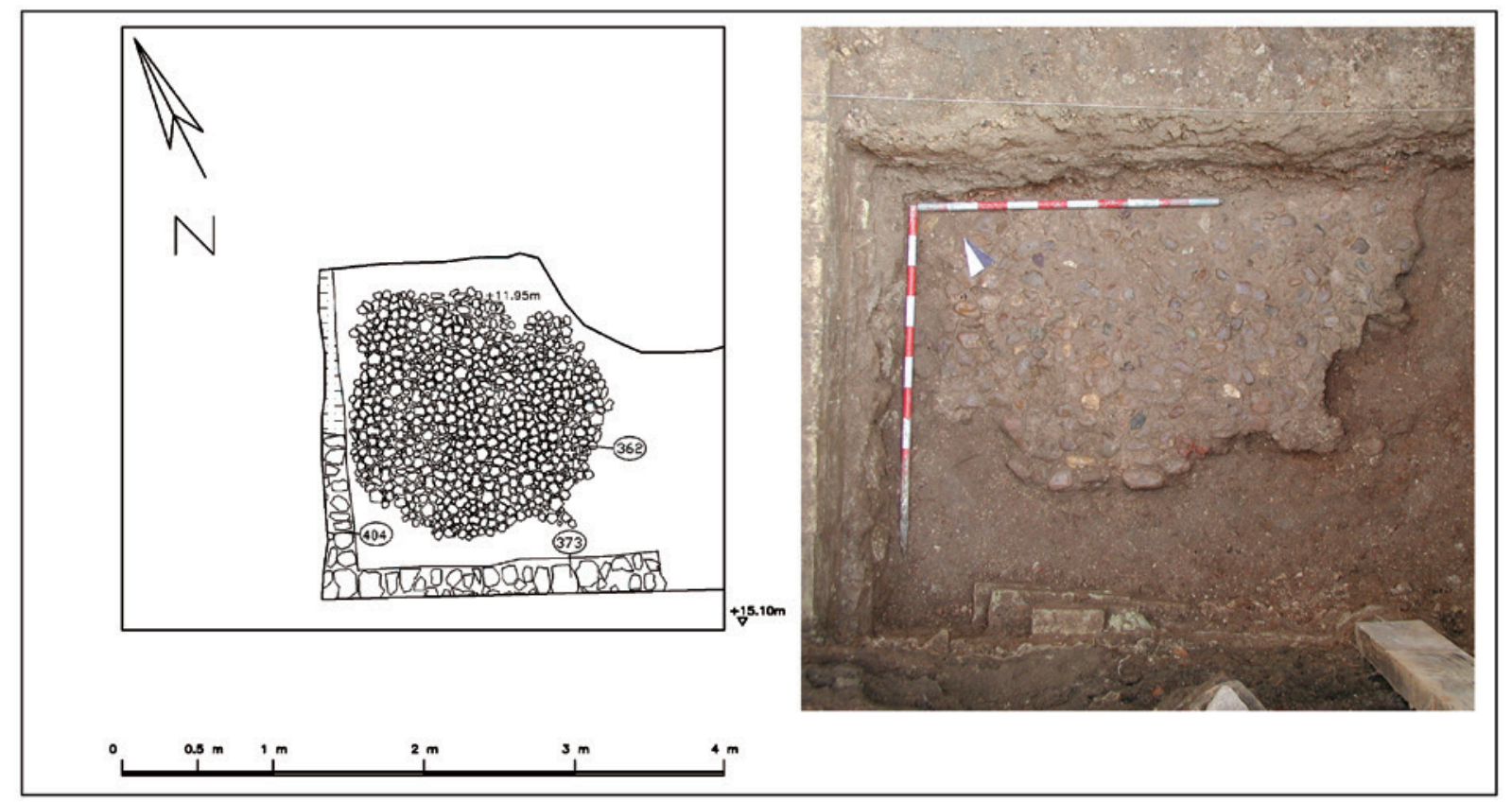

Fig. 7. Estructura 6. 


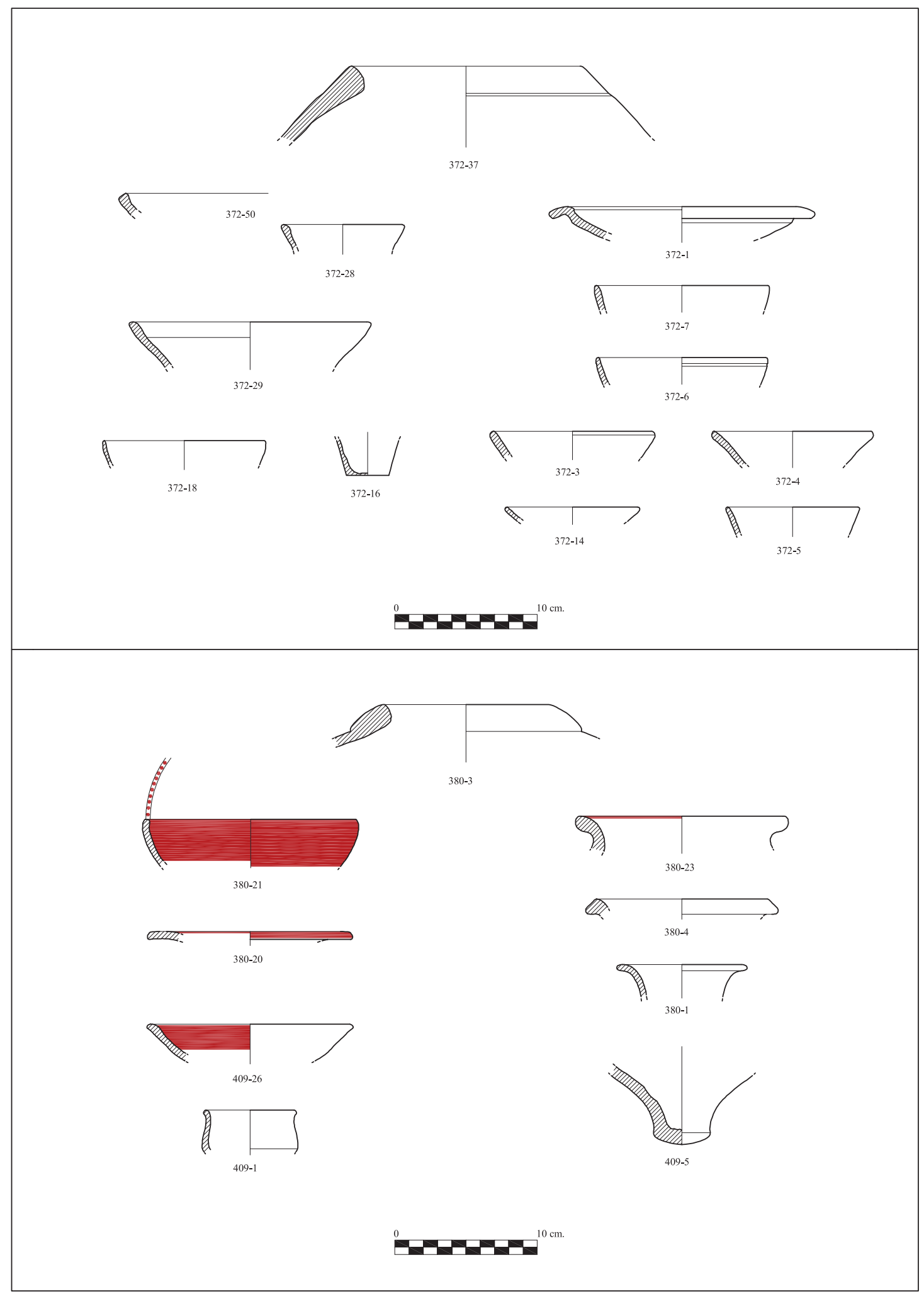

Lámina 7. UU.EE. 372, 380 y 409. 
(130/120-90/80 a.C.), y por un bol asimilable a la forma 2614 de Morel (Lám. 9: 371-39). El color amarillento de la pasta del bol M.2614 y la mala calidad de su barniz hacen dudar de su pertenencia al taller de Cales, por lo que se trata probablemente de un ejemplar del círculo de las $\mathrm{B}$ más que de una $\mathrm{B}$ calena propiamente dicha. En la campaniense de Cales, la forma M.2614 es en realidad más común en el repertorio de la variante antigua (200/130-120) que en el de la media, aunque estos boles están presentes aún en Valencia en contextos del último cuarto del siglo II a.C. (Escrivá y otros 1992: 457).

Una procedencia no campana, sino etrusca, puede atribuirse a un borde de campaniense B de la forma 5 de Lamboglia. Se trata de una pieza de indudable calidad técnica lo que, unido a su fina pasta beige sin desgrasantes visibles y a su barniz satinado y denso de color negro azulado, nos inclina a clasificarlo como un producto norditálico. La cronología inicial de las páteras de la forma 5 de Lamboglia en campaniense B etrusca o "verdadera" se remonta al último cuarto del siglo II a.C. (Principal 2005: 54).

Entre las importaciones itálicas de la unidad se documenta la presencia de un fragmento amorfo de cerámica "megárica". Se trata de un bol del que se conserva un pequeño fragmento correspondiente a la zona situada bajo el borde, decorada, como es habitual en estas producciones, con motivos geométricos. El fragmento, de color gris oscuro, conserva parte de dos bandas de decoración superpuestas de las que en la superior se aprecia una roseta y en la inferior un motivo de líneas paralelas en zig-zag. La pasta cerámica de esta pieza delata su procedencia en los talleres norditálicos que a partir en los siglos II y I a.C. imitaron las producciones de Mégara (Puppo 2006).

Junto a las importaciones itálicas, se documenta en la UE 371 un amplio conjunto de cerámicas comunes que podrían adscribirse sin problemas a talleres locales del sur peninsular (Lám. 8). Predomina claramente la cerámica de tradición turdetana, aunque algunas piezas parecen trascender este círculo, mostrando una vez más claras correspondencias con el repertorio característico del ámbito púnico-gaditano.

Un borde de ánfora del tipo 9.1.1.1 de Ramón (1995: 226-227) o CC.NN. puede atribuirse con seguridad a los centros productores de la bahía de Cádiz (Lám. 8: 371-119). Los talleres de la Isla de San Fernando son los que hasta el momento han ofrecido los datos cronológicos mejor contrastados para una forma cuyo momento de máxima producción parece haber sido la segunda mitad de siglo II a.C. (Ramón 1995: 227), si bien también podrían llegar hasta la primera mitad del I, como se ha observado recientemente en los hornos de Pery Junquera (Carretero 2004: 433). Un par de bordes de cerámica común pueden adscribirse igualmente a talleres gaditanos, o al menos a la influencia de la morfología púnico gadirita. El primero corresponde a una cazuela de la recién definida forma GDR 11.1.1 (Lám. 8: 371-157), cuyo principal rasgo es la presencia de una ranura en el borde para servir de apoyo a una tapadera (Sáez 2005: 162-163). Estos recipientes fueron fabricados en los talleres tardopúnicos de San Fernando entre las últimas décadas del siglo III a.C. y los años finales del II a.C. en dos variedades de pasta: con engobe y pastas claras o con superficie y núcleo marrón oscuro o gris. La pieza de Abades remite a esta última variedad, con la que comparte, si no la abundancia, sí al menos la presencia de desgrasantes cuarcíticos y micáceos. El segundo fragmento cerámico de posible ascendencia púnica hallado en el depósito UE 371 corresponde a un borde de jarra provista de un asa de sección subrrectangular que arranca del mismo labio (Lám. 8: 371-83). Se asemeja a la forma GDR 10.2.1 (Sáez 2005: 160-161), propia de la bahía de Cádiz, donde la encontramos ya presente en los años centrales del siglo III, aunque puede perdurar al menos hasta mediados del siglo II a.C. (ibidem).

El resto de las cerámicas comunes y pintadas de la unidad corresponde a piezas de tradición turdetana cuya morfología remite, en gran medida, al repertorio configurado en el Bajo Guadalquivir a finales del siglo IV a.C. Destacan por su número los lebrillos de grandes dimensiones $(45-50 \mathrm{~cm}$. de diámetro), cuyos bordes tienden ahora a ser más robustos que los de época prerromana, predominando los perfiles de sección redondeada o subrrectangular (Lám. 9: 371-85, 87 y 120). Cuentan con paralelos en los niveles 1 y 2 de Cerro Macareno (Pellicer y otros 1983: fig. 17 y 19), así como en los niveles 18 y 19 de Argote de Molina 7, ya en la propia Sevilla (Campos 1986: fig. 34 y 40). Un ejemplar de menor tamaño $(24,4 \mathrm{~cm}$. de diámetro) está decorado en el interior con trazos verticales de color rojo (Lám. 8: 371-45), una característica que se hará frecuente, con esquemas compositivos de mayor o menor complejidad, ya en la centuria siguiente.

Las urnas de cuello corto con o sin decoración pintada y los cuencos de casquete esférico también siguen los esquemas formales del período prerromano. Entre estos últimos predomina la variante de borde redondeado, habiendo desaparecido a lo largo del siglo II los cuencos de borde biselado, tan característicos del siglo III a.C. (García Vargas y otros 1989); mientras que los de pared entrante sin decoración pintada prefiguran la forma de los cuencos de engobe claro que pasarán al 


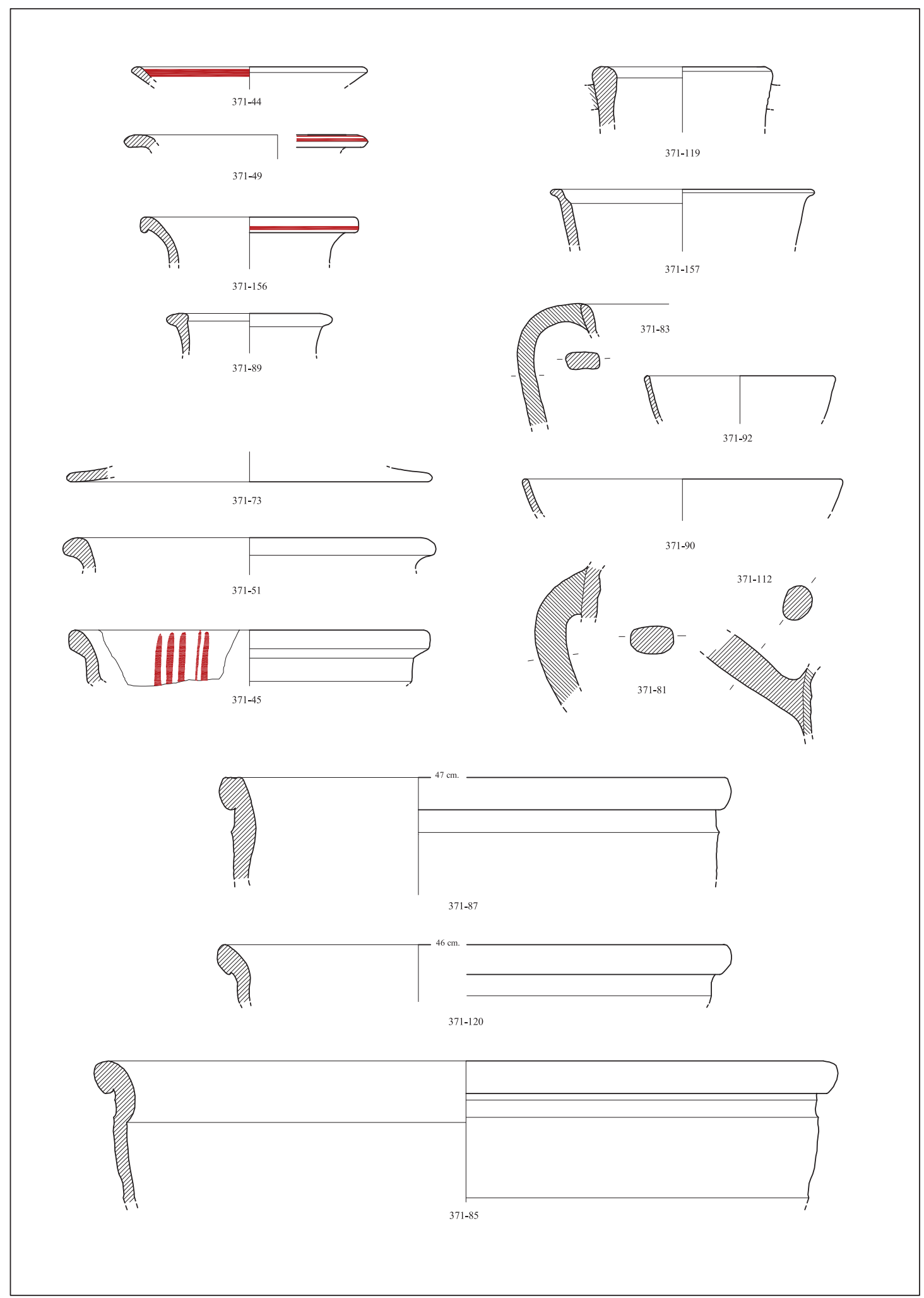

Lámina 8. UE 371 (producciones locales). 
repertorio de las cerámicas comunes durante el siglo I d.C. (Serrano 1995: 237-238).

Mención aparte merecen las urnas globulares o bitroncocónicas con asas de "orejeta" (forma IX de Escacena). Si bien sus prototipos se remontan en Carmona al período orientalizante, el momento de máxima producción en el valle del Guadalquivir parece situarse entre la segunda mitad del siglo III y mediados del siglo II a.C. como demuestran los ejemplares de Cerro Macareno (Pellicer y otros 1983: fig. 27) y La Tiñosa (Belén y Fernández-Miranda 1978: fig. 20). No obstante, la forma se documenta también en el siglo I a.C. en Itálica (Luzón 1973: lám. XVII) y en la centuria siguiente en Carmona (Bendala 1976: lám. ILVI-21). De la UE 371 de Abades proceden dos fragmentos de asa de este tipo, una de las cuales conserva en el arranque parte de la carena correspondiente al tercio superior del vaso (Lám. 8: 371-81 y 112).

En su conjunto, los materiales procedentes del encachado cerámico UE 371 remiten, pues, a un momento dentro del último cuarto del siglo II a.C., lo que indica que la Estructura 5, construida en el tercio central del siglo II a.C., fue reformada mediante la sustitución del pavimento en los decenios finales de la misma centuria. El pavimento UE 371 representa además el último de los episodios de ocupación de la Estructura 5. Las unidades que se le superponen corresponden ya a la anulación de la ésta última para la construcción de la siguiente estructura, la $n^{\circ} 6$ (Fig. 8), una "vivienda" cuya descripción y análisis quedan casi completamente fuera de los límites cronológicos del presente trabajo, pero cuya datación permitiría establecer un término ante quem para la amortización de la Estructura 5. A esta anulación corresponden tres vertidos superpuestos (UU.EE. 363-370, 369 y 362) de los cuales el primero, un nivel de matriz arcillosa y abundantes inclusiones de ceniza y cal, es el único que ha ofrecido materiales arqueológicos diagnosticables, reducidos, sin embargo, a un borde de mortero campano del tipo Emporiae 36.2 (segunda mitad del siglo II-segunda mitad del siglo I a.C.) y a un asa y algunos fragmentos atípicos de una ánfora ibicenca encuadrable en los tipos 8.1.3.2 o bien 8.1.3.3 de Ramón. El primero se fecha entre 200 y 120 , mientras que la cronología del segundo se extiende entre 120-100 a.C. y 50-75 d.C. (Ramon 1995: 224-225). Si los fragmentos de esta unidad correspondieran a un ejemplar del segundo de los tipos citados, la fecha de amortización de la Estructura 5 podría situarse en el siglo I a.C. No obstante, cabe también la posibilidad de que se trate de un ejemplar residual del tipo 8.1.3.2, contemporáneo, por tanto, a los amorfos de Campaniense A media junto a los que comparece en la misma UE. Por otra parte, el carácter residual de la mayoría del material registrado en la unidad 363-370, entre el que se documenta incluso la presencia de cerámica a mano bruñida o con decoración pintada tipo Carambolo, tampoco permiten sustentar con claridad ninguna de las dos posibilidades.

Los niveles constructivos de la Estructura 6 (Fig. 8) tampoco proporcionaron material datante contemporáneo a la fundación de la misma. La UE 364, una zapata de ladrillos que constituye el cimiento del muro UE 315, ofreció un bol en campaniense A de la forma Lamb. 27a-b cuya cronología alcanza la mitad del siglo I a.C. en su variante tardía. En este caso, se trata de un fragmento tecnológicamente encuadrable en la variante media, por lo que debe considerarse residual en este contexto. Igualmente residual parece ser el resto de los materiales documentados en la misma unidad: un pivote y un asa de Dressel 1, así como los bordes de un cuenco, una pequeña urna sin pintar y un lebrillo de tradición turdetana.

El único contexto de la Estructura 6 que proporcionó material aproximadamente contemporáneo a su ejecución fue la UE 366, un nivel de reparación del segundo de los pavimentos de signinum que conformaron la misma. Proceden de aquí un borde de Haltern 70 de morfología tempranoaugustea y otro de un ánfora ibicenca del tipo PE 25 (Ramón 1991: 119-22). La reforma del pavimento de signinum puede fecharse en función de este escaso material hacia el último cuarto del siglo I a.C. La construcción de la Estructura 6, que incluiría la de su primitivo pavimento de guijarros (UE 362), es necesariamente anterior a esta fecha (Fig. 7). Lo mismo vale para el proceso de amortización de la Estructura 5. Ambos episodios debieron sucederse en el tiempo entre 100 y 25 a.C. sin que pueda proponerse una datación más precisa para ninguno de ellos.

\section{EVOLUCIÓN DE LOS REPERTORIOS CERÁMICOS}

Tanto el estudio de los conjuntos cerámicos turdetanos, como la adscripción cronológica y cultural de los contextos de ocupación o amortización en los que fueron hallados, se ha llevado a cabo mediante un análisis comparativo con otras secuencias análogas documentadas en el valle bajo del Guadalquivir durante los años 70 y 80 del pasado siglo. Se trata fundamentalmente de las excavaciones llevadas a cabo en el Pajar de Artillo (Luzón 1973) y en el Cerro de la Cabeza de Santiponce (Domínguez de la Concha y otros 1988), el corte V-20 del Cerro Macareno en La Rinconada (Pellicer y otros 1983), 


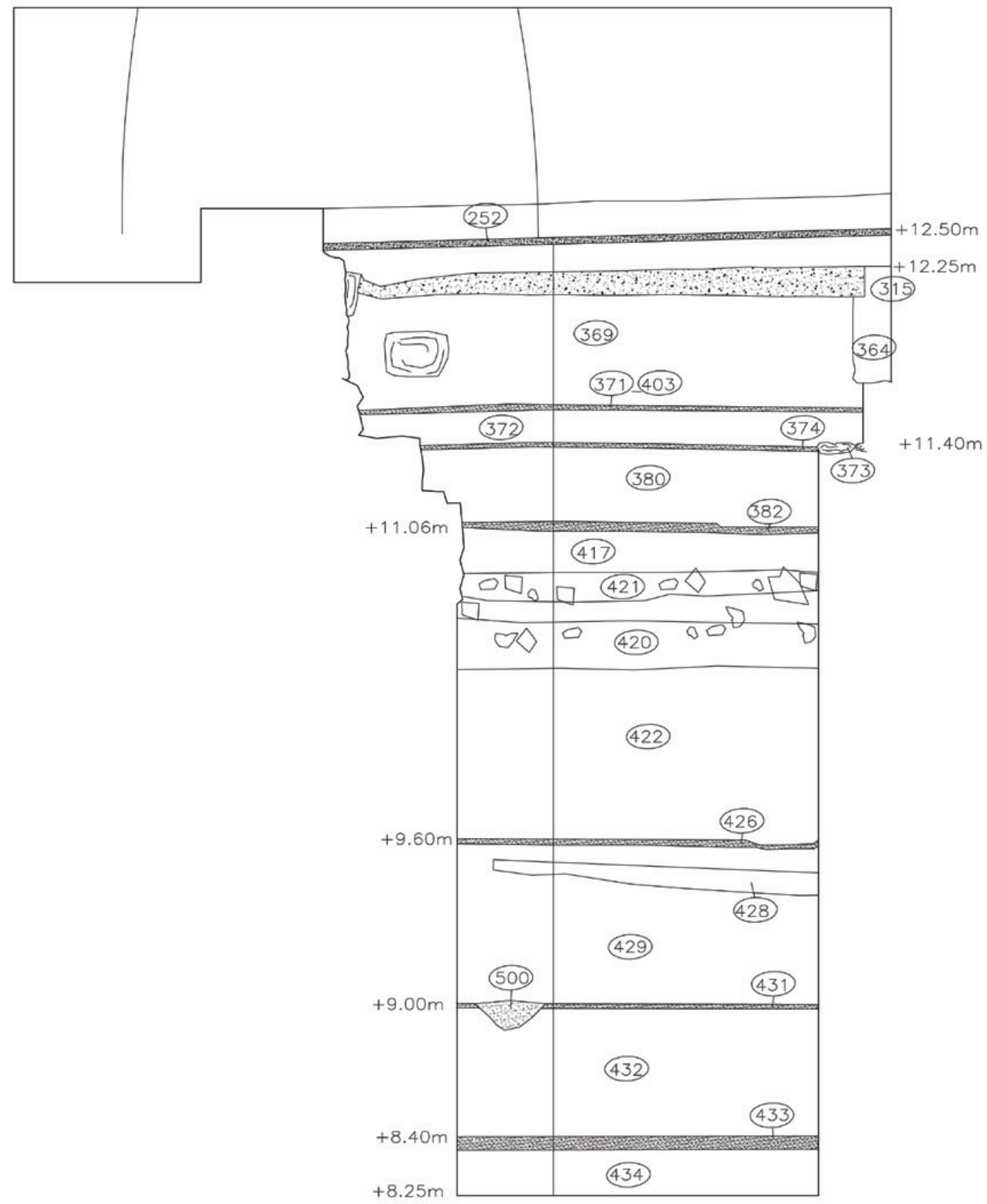

Fig. 8. Perfil Este. 
los últimos niveles de ocupación de Montemolín (García Vargas y otros 1989) y poblado de Vico (Bandera y Ferrer 2002), ambos en término municipal de Marchena, así como las intervenciones practicadas en el casco urbano de Carmona (Carriazo y Raddatz 1960; Pellicer y Amores 1985). Ya en Sevilla, contamos con las excavaciones llevadas a cabo en el número 7 de la calle Argote de Molina (Campos 1986) y en los números 21-23 de San Isidoro (Campos y otros 1988). La misma metodología comparativa ha servido para el estudio y datación de los conjuntos de tradición turdetana presentes en los contextos estratigráficos de época republicana, donde los materiales cerámicos de origen local o regional suelen ser mayoritarios. En este caso, la presencia en mayor o menor grado de cerámicas de importación ha sido fundamental para articular cronología y para seguir en el tiempo la evolución morfológica y funcional de los repertorios cerámicos en consideración.

\section{Los contextos prerromanos}

En los contextos de los siglos IV y III a.C. nos encontramos ya la vajilla turdetana plenamente conformada $^{1}$. Se trata, como hemos puesto de relieve en anteriores ocasiones (García Fernández 2007:130), de un reducido elenco de formas heredadas del periodo orientalizante, resultado de la fusión entre la tradición cerámica local y los nuevos prototipos llegados de Oriente. Llama especialmente la atención su monotonía, sobre todo si la comparamos con los repertorios característicos del área ibérica (Pereira 1989). A esta disminución en la variedad de recipientes, que hemos atribuido a una adaptación de las producciones a torno a las necesidades cotidianas de las poblaciones locales del Bajo Guadalquivir, una vez asimiladas las novedades tecnológicas derivadas del impacto colonial, habría que unir un proceso de estabilización e incluso fosilización de las formas principales, que apenas acusan cambios a lo largo de la II Edad del Hierro. Nos estamos refiriendo, esencialmente, a los cuencos de casquete esférico, ya sean de borde simple o engrosado, los platos de labio vuelto y caído, los lebrillos de cuello estrangulado y

1. . Empleamos el término "turdetano" con un sentido cronológico y geográfico, para hacer referencia a las poblaciones de la Baja Andalucía durante la II Edad del Hierro, y no desde el punto de vista cultural y mucho menos étnico (García Fernández 2002). Partimos de la consideración de que tras la aparente homogeneidad que se aprecia en el registro material se esconde una realidad paleoetnológica mucho más compleja, como resultado de los procesos de interacción, diferenciación y/o mestizaje derivados del proceso colonial, especialmente intenso en la antigua desembocadura del Guadalquivir. las urnas globulares y/o bitroncocónicas, que evolucionan respectivamente de las urnas "Cruz del Negro" y del vaso "à chardon" de época orientalizante (Bandera y Ferrer 2002: 146). Conforman, como acabamos de ver, el repertorio habitual en los niveles prerromanos de la calle de Abades, así como, en general, de la ciudad de Sevilla, al menos hasta el cambio de era (García y González 2007). Por otra parte la cerámica a mano, que tiende a desaparecer en los contextos del Bajo Guadalquivir desde finales del siglo VI a.C. o inicios del $\mathrm{V}$, es prácticamente testimonial en el corte $15 \mathrm{~A}$ a excepción de las ollas de cocina, que perdurarán aún durante algún tiempo, al menos hasta bien entrado el siglo IV a.C. Ello no es óbice, sin embargo, para que aparezcan, junto a estos recipientes, restos de cerámica a mano o a torno de periodos anteriores (fragmentos de vasos "à chardon", cerámica gris, cerámica de engobe rojo, etc.), procedentes en todo caso de la alteración de los niveles precedentes.

A partir de mediados del siglo IV a.C. se asiste también a una caída generalizada de las importaciones griegas, que afecta tanto a las ánforas como a las cerámicas de barniz negro y figuras rojas. Este fenómeno ha podido observarse no sólo en la ciudad de Sevilla, sino en otros asentamientos de su entorno inmediato, así como también en el área de influencia púnica, donde la vajilla de mesa es sustituida poco después por las producciones gaditanas de tipo "kuass" (Niveau 2003). En el corte $15 \mathrm{~A}$ de Abades la cerámica griega se encuentra ya totalmente ausente, al menos en los niveles excavados, lo que resulta coherente con la fecha propuesta para el inicio de los primeros contextos de ocupación documentados (finales del siglo IV a.C.). Esta carencia limita en gran medida nuestra capacidad para establecer cronologías ajustadas, por lo que nos hemos visto obligados a recurrir a las ánforas como principales elementos de datación y al análisis comparativo con otras secuencias estratigráficas con el fin de establecer unas pautas generales en la evolución de los conjuntos cerámicos del Bajo Guadalquivir desde finales del siglo $\mathrm{V}$ hasta la llegada masiva de importaciones itálicas en la segunda mitad del siglo II a.C.

Por lo que respecta a las ánforas, a partir de finales del siglo VI a.C. se produce una evolución de los contenedores fenicios occidentales que darán lugar, paralelamente, tanto a las ánforas púnicas del área del Estrecho (Mañá-Pascual A4 o Cádiz A4), destinadas al envasado de salazones y salsas de pescado (De Frutos y Muñoz 1996: 142), como a los tipos propiamente turdetanos, concretados en la forma B-C de Pellicer y sus variantes (Pellicer 1982: 390-392). Sin embargo, se trata en este último caso de un espécimen poco habitual en los 
niveles prerromanos de la excavación de Abades, hecho que también se constata en otras excavaciones llevadas a término en el casco histórico de la ciudad (García y González 2007: 551). Por el contrario, desde finales del siglo V e inicios del IV a.C. se asiste en Sevilla a un extraordinario incremento en el volumen de ánforas procedentes del ámbito púnico, no sólo variantes del tipo Mañá-Pascual A4 (Lám. 1: 432-1) sino, sobre todo, de nuevas producciones que tienen su origen en la campiña de Cádiz, especialmente la zona de Jerez y el valle del Guadalete (Ferrer y García, e.p.). Se trata de las ánforas T-8.1.1.2 (Ramón 1995: 222), conocidas comúnmente como "tipo Tiñosa" (Rodero 1991) o Muñoz E-1 (Muñoz 1987) (Lám. 4: 422-52), a las que habría que añadir a finales del siglo IV a.C. las T-8.2.1.1 (Ramón 1995: 225-226), clasificadas como "tipo Carmona" por Rodero o Muñoz A5 (Lám. 4: 422-53). Su claro predominio sobre los envases de fabricación local, no sólo en la ciudad de Sevilla sino, en general, en las localidades ribereñas de la antigua desembocadura del Guadalquivir, pone de manifiesto el inicio de un nuevo despliegue comercial púnico en la Baja Andalucía, encabezado de nuevo por Cádiz, que no decaerá al menos hasta la segunda mitad del siglo I a.C. (Ferrer y García, e.p.).

Durante el siglo III a.C. se generaliza además la forma D de Pellicer, cuya producción, si bien en origen pudo haberse emplazado también en el hinterland de Cádiz (Niveau 2002: 242), no cabe duda de que posteriormente ésta se extendería por el Guadalquivir y sus campiñas interiores. Cronológicamente la difusión de estos contenedores coincide en parte con la del ánfora "tipo Carmona", aunque se mantendrá algunos años más, llegando en sus variantes más tardías al tercer cuarto del siglo I a.C. La total ausencia de este espécimen en los contextos prerromanos analizados pudo deberse seguramente al azar, ya que en cambio sí es habitual, como veremos, en los niveles de época romanorepublicana.

Junto a estas ánforas arriban también al puerto de Sevilla otras producciones procedentes de los talleres gaditanos: fundamentalmente cerámica tosca o de cocina y, a partir del siglo III, algunas de las formas más corrientes de la vajilla tipo "kuass" (García y González 2007: 555). De esta última sólo se ha documentado en el corte 15A un fragmento atípico procedente de la UE 418. La cerámica tosca, en cambio, se encuentra bien representada por los morteros, que hacen su aparición en el Bajo Guadalquivir a inicios del siglo IV a.C. Como ya observara Ruiz Mata (1987: 311), los ejemplares más antiguos suelen presentar el borde largo y aplanado, con una suave acanaladura en la parte superior, "mientras que los más recientes ofrecen apéndices interiores, bordes más gruesos y, en algunos casos, hendiduras amplias en la zona superior del borde" (Lám. 5: 419-3).

El análisis exhaustivo de la cerámica común y pintada también permite desprender algunos matices cronológicos y culturales a la aparente homogeneidad de los repertorios turdetanos. Para empezar, se puede observar una paulatina mejora en la calidad de las arcillas y en los procedimientos de cocción, que dan como resultado unas pastas oxidantes, muy uniformes, con tonos que van del crema al anaranjado o rojizo. La cocción alterna, hasta entonces predominante, pasa a ocupar un segundo plano a partir del siglo III, para ser minoritaria ya en el siglo II a.C. (García y González 2007: 557). Al mismo tiempo asistimos a una lenta pero continua reducción de la decoración pintada, que se limita ahora a líneas y bandas de color rojizo, sólo en ocasiones alternadas con filetes negros o de otro color. Esta tendencia afecta sobre todo a los lebrillos, que a partir de finales del siglo IV a.C. prácticamente no se decoran. Lo mismo se puede decir de los cuencos, aunque en este caso, al igual que ocurre con los platos, siempre va a existir un número variable de especímenes que mantengan a la altura del borde la banda ancha de color vinoso que caracteriza a estas producciones. En el lado opuesto se encuentran las urnas, principalmente las de cuello acampanado, que acusan a finales del siglo III a.C. un amplio desarrollo del aparato decorativo ${ }^{2}$. El corte 15A de Abades sólo ha proporcionado ejemplares en estado muy fragmentario, aunque puede resultar sugerente advertir que en todos los casos los bordes conservan un revestimiento de color rojo bruñido, mientras que entre los fragmentos atípicos encontramos bandas y líneas rojizas alternadas con filetes negros o anaranjados, trazos verticales de color oscuro, círculos concéntricos, etc. Volviendo a los cuencos, son frecuentes a partir del siglo III a.C. los especimenes que presentan labio cortado a bisel, tanto al interior como al exterior, o por ambas caras (García Vargas y otros 1989: 224), aunque por ahora se trata de una variante poco conocida en la ciudad de Sevilla (Lám. 5: 417-38).

Pero quizá el principal rasgo que caracteriza a los repertorios cerámicos de los siglos IV y III a.C. sea la incorporación de formas nuevas, cuya producción se estandariza en este momento. Es probable que en ello

2. . Es lo que se observa, por ejemplo, en Itálica (Luzón 1973: lám. I), donde estas urnas suelen decorarse con dos bandas anchas de color rojo enmarcadas, en ocasiones, por líneas negras que se sitúan respectivamente sobre los hombros y en el tercio inferior del cuerpo, bajo el diámetro máximo. Entre ambas pueden aparecer eventualmente haces de 3 o 4 líneas verticales onduladas. 
tenga algo que ver la intensa helenización a la que se ve sometida la vajilla púnica y la ibérica (Escacena 1992: 326), aunque en la mayor parte de los casos lo que nos encontramos es una recuperación o reinterpretación de prototipos formales ya conocidos, como ocurre por ejemplo con el pequeño vaso de perfil en S o "vaso para beber" (Fernández Gómez y otros 1979: 44)3. Se trata, como hemos visto, de recipientes de pequeño tamaño, con base plana o anular y borde indiferenciado. Escacena (1987: 363) establece dos variantes a partir del perfil del cuerpo: una carenada, que encontramos ya presente a finales del siglo $\mathrm{V}$, aunque puede perdurar hasta el siglo III a.C. (Lám. 2: 426-10), y otra de perfil sinuoso, mucho más abundante que la anterior, que se difunde a finales del siglo IV o inicios del III a.C. Dado el lamentable estado de conservación de la mayor parte de los ejemplares hallados en el corte 15A, resulta difícil adscribirlos a un subtipo u otro, aunque en cualquier caso se trata de una especie habitual en los contextos de los siglos IV al II a.C.

Otra forma característica de los siglos IV y III a.C. es el cuenco-lucerna (Lám. 3: 423-24). Aunque recipientes de este tipo aparecen ya a finales del siglo VI en Cerro Macareno (Pellicer y otros 1983, fig. 59), en realidad su uso no se extiende hasta finales del V o inicios del siglo IV a.C. Escacena (1987: 335-336) distingue de nuevo dos variantes en función de si están provistas o no de carena. Los ejemplares de perfil suave, mucho más antiguos, son además los más frecuentes en el Bajo Guadalquivir, perdurando hasta el siglo I a.C. La variante carenada, poco habitual en la ciudad de Sevilla, cuenta por su parte con un desarrollo cronológico limitado, que se ciñe a los siglos III y II a.C. (García y González 2007: 553). También se difunden en este momento las urnas con baquetón, clasificadas por Escacena como Forma XX (Lám. 3: 423-35). En realidad bajo esta denominación se reúne un conjunto amplio de vasos cerrados de tamaños y perfiles variados (ovoides, globulares o bitroncocónicos) cuyo denominador común es la presencia de un resalte o moldura a la altura del hombro. Esta última suele dejarse en reserva, aunque también puede ir decorada con líneas paralelas, puntos, trazos verticales u oblicuos, etc. (Escacena 1987: 611). Los ejemplares más antiguos se documentan ya en el estrato 3 de Carmona (Carriazo y Raddatz 1960: 24, fig. 6), de finales del siglo VI a.C. (Escacena

3. A pesar de que Luzón puso en relación su aparición con la difusión de los vasos de orfebrería de origen aqueménida en época helenística (Luzón 1973: 39), nosotros pensamos más bien que esta forma debe responder a una adaptación del vaso "à chardon" de época orientalizante (García Vargas y otros 1989: 231).
1987: 612), así como en el nivel 17 de Cerro Macareno, fechado a principios del siglo V (Pellicer y otros 1983, fig. 53); no obstante, se trata de un recipiente habitual sobre todo en los contextos de los siglos IV y III, pudiendo alcanzar el II a.C. (Luzón 1973: 45-46).

Ya en el siglo III a.C. hacen su aparición las urnas globulares u ovoides de gran formato (Escacena IX). Se caracterizan por la presencia de asas laterales de sección acanalada, generalmente en posición vertical, así como por un cuello corto y cilíndrico muy característico (Escacena 1987: 398). Las asas suelen situarse, como hemos podido comprobar, hacia la mitad del recipiente, justo donde éste alcanza el diámetro máximo, o bien en el extremo superior, entre el borde y los hombros. Por su parte, la decoración se limita a bandas estrechas y líneas de color rojizo que pueden aparecer aisladas o agrupadas bajo el cuello y en el tercio central.

Por lo que respecta a la cerámica de cocina, cabría señalar únicamente la estandarización en la segunda mitad del siglo IV a.C. de un tipo de olla que aparecerá con frecuencia en los contextos del siglo III e inicios del II a.C. Se trata de un recipiente de mediano tamaño, de factura grosera y pastas oscuras, cuyo principal rasgo es el desarrollo de un borde engrosado de sección oval o almendrada y tendencia vertical o ligeramente pronunciado al exterior (Lám. 3: 423-1 y 6). Se halla presente, como decimos, en la mayor parte de los contextos documentados en el Bajo Guadalquivir, como puede ser el caso de Vico (Bandera y Ferrer 2002: fig. 13), Cerro Macareno (Pellicer y otros 1983: fig. 24), Itálica (Luzón 1973: Lám. XX), o la propia Sevilla (García y González 2007: 556-557).

En resumen, nos encontramos ante un repertorio marcadamente local, como puede comprobarse sobre todo en la cerámica a torno común y pintada: cuencos, platos, lebrillos, urnas, etc. La introducción de producciones procedentes del entorno de Cádiz afecta principalmente a las ánforas, así como a determinadas formas de la cerámica común y a la vajilla de mesa. En el primer caso, la llegada masiva de contenedores de filiación púnica sólo puede explicarse como resultado de una intensificación y diversificación de las relaciones comerciales con Gadir, que se orientan ahora a la importación y redistribución de productos agrícolas (aceite y vino fundamentalmente) y derivados de la pesca (Ferrer y García, e.p.). Por su parte, la adquisición de cerámica común se limita en el siglo III a formas muy concretas relacionadas con la preparación de alimentos. Es lo que ocurre con los morteros y algunas ollas de cocina (estas últimas ausentes en la estratigrafía de Abades). Al igual que sucede con la cerámica tipo "Kuass", cuya presencia en los contextos turdetanos de la ciudad 
de Sevilla sigue siendo por ahora testimonial, la introducción de estos especimenes en los repertorios locales apenas modifican la composición morfológica y funcional de la cerámica doméstica, que sigue orientada a satisfacer las mismas necesidades que en los siglos anteriores. Esto vendría a confirmar las ideas expuestas más arriba sobre el carácter conservador de la cerámica "turdetana".

\section{Los contextos romano-republicanos}

Con la recepción (y amortización en nuestra secuencia) de las cerámicas de importación itálicas, se hace posible valorar de forma más ajustada los contextos arqueológicos en consideración, y no sólo desde el punto de vista cronológico. Antes de la construcción de la Estructura 5, la presencia de cerámicas campanas en el corte $15 \mathrm{~A}$ de Abades es testimonial. La recepción de cierta cantidad de vajilla de barniz negro romano se produce en los contextos de construcción y uso de ésta última estructura. Comparecen en un primer momento las campanienses A en su variante media, caracterizadas por una pasta de color rojo o marronácea, dura, granulosa, con escasos desgrasantes identificables a simple vista y algunas inclusiones micáceas. Los barnices son en casi todas las piezas homogéneos, de reflejo metálico y aspecto lucente, correspondiendo la morfología de los recipientes a platos, boles y copas (Lám. 7).

Platos, boles y copas con las mismas características tecnológicas se documentan en los niveles de refacción del pavimento de la Estructura 5 (Lám. 9), aunque ahora observamos ciertos signos de "descuido" en la ejecución de los recipientes, especialmente en lo que se refiere a los barnices. Éstos, sin perder su aspecto lucente, se hacen menos homogéneos, presentando en la superficie de los vasos zonas no cubiertas o cubiertas de forma imperfecta, normalmente en la parte exterior del pie, pero no sólo aquí. No puede decirse, sin embargo, que se trate de campanienses de la variante tardía, ni por el aspecto de los barnices, ni por la solución formal de los fondos, que no presentan aún en la unión entre la pared externa del vaso y el anillo del pie el "escalón" característico de las producciones tardías. A la variante media de las campanienses A de Abades habría que sumar la aparición, a partir de este momento, de un plato, una copa y un bol en campaniense B. El primero (Lamb. 5), muy fragmentado, presenta el barniz satinado de reflejos azulados y la pasta homogénea y beige propia de las campanienses "verdaderas" o etruscas; el segundo (Lamb. 1) es un fondo de la variedad calena con pasta beige y barniz poco denso, negro castaño y de iridescencias grisáceas
(Lám. 9: 371-40); mientras que el tercero es un pequeño bol de pasta amarillenta y barniz castaño oscuro muy degradado, especialmente en el exterior de la pieza, lo que la incluye en el llamado "círculo de las B" de problemática definición (Lám. 9: 371-39).

La evolución del repertorio de barniz negro en Abades a lo largo del último tercio del siglo II a.C. es coherente con lo que sabemos acerca de los ritmos de recepción de la vajilla de barniz negro en el sur de Hispania, al menos en lo referido a las clases cerámicas presentes. En la costa de Andalucía oriental, por ejemplo, la sustitución de las producciones de la clase A por la de la clase B no se verifica hasta los años iniciales del siglo I a.C. (Adroher 2000). En Sevilla, el material de barniz negro procedente de la excavación llevada a cabo en el número 7 de la calle Argote de Molina (Campos 1986), más abundante que el de Abades y que hemos tenido la oportunidad de revisar recientemente en el Museo Arqueológico de Sevilla, ofrece en efecto para los decenios iniciales de la primera centuria un panorama dominado porcentualemente por las campanienses B, que representan un $57,45 \%$ frente a un $42,55 \%$ de la clase A. Dentro de las campanienses B de Argote, las calenas representan un 50\%, mientras que las etruscas o "verdaderas" constituyen un $36,36 \%$, siendo el resto de difícil atribución.

A nivel morfológico, no se constata en Abades una cesura importante entre los niveles de construcción de la Estructura 5 y los de repavimentación de la misma. Ambos se componen de platos, copas y boles. El reducido número de piezas con que trabajamos no nos permite constatar aquí desarrollos cuantitativos referidos a la proporción de una clase funcional con relación a la otra, aunque la estratigrafía de Argote de Molina parece abogar por un aumento considerable de los platos de la forma 5 (escasamente representados en Abades) en todas las clases y variantes de barniz negro, a partir de inicios del siglo I a.C.

La presencia significativa en nuestra excavación de copas - con asas o no- y de boles es tal vez coherente con la poca incidencia en la misma de los recipientes de paredes finas (de nuevo más frecuentes en Argote de Molina), lo que quizá sugiera una funcionalidad específica para la mayoría de los recipientes de barniz negro registrados en Abades: la de vasos para beber. La documentación en la UE 371 de ánforas vinarias del tipo Dressel 1 con pastas campanas remite a la misma procedencia geográfica que las cerámicas campanienses mayoritarias en la unidad (Nápoles-Ischia). Este hecho podría estar indicando una selección intencionada del repertorio relacionado con el consumo del vino y justificaría, al mismo tiempo, la repentina irrupción de las 


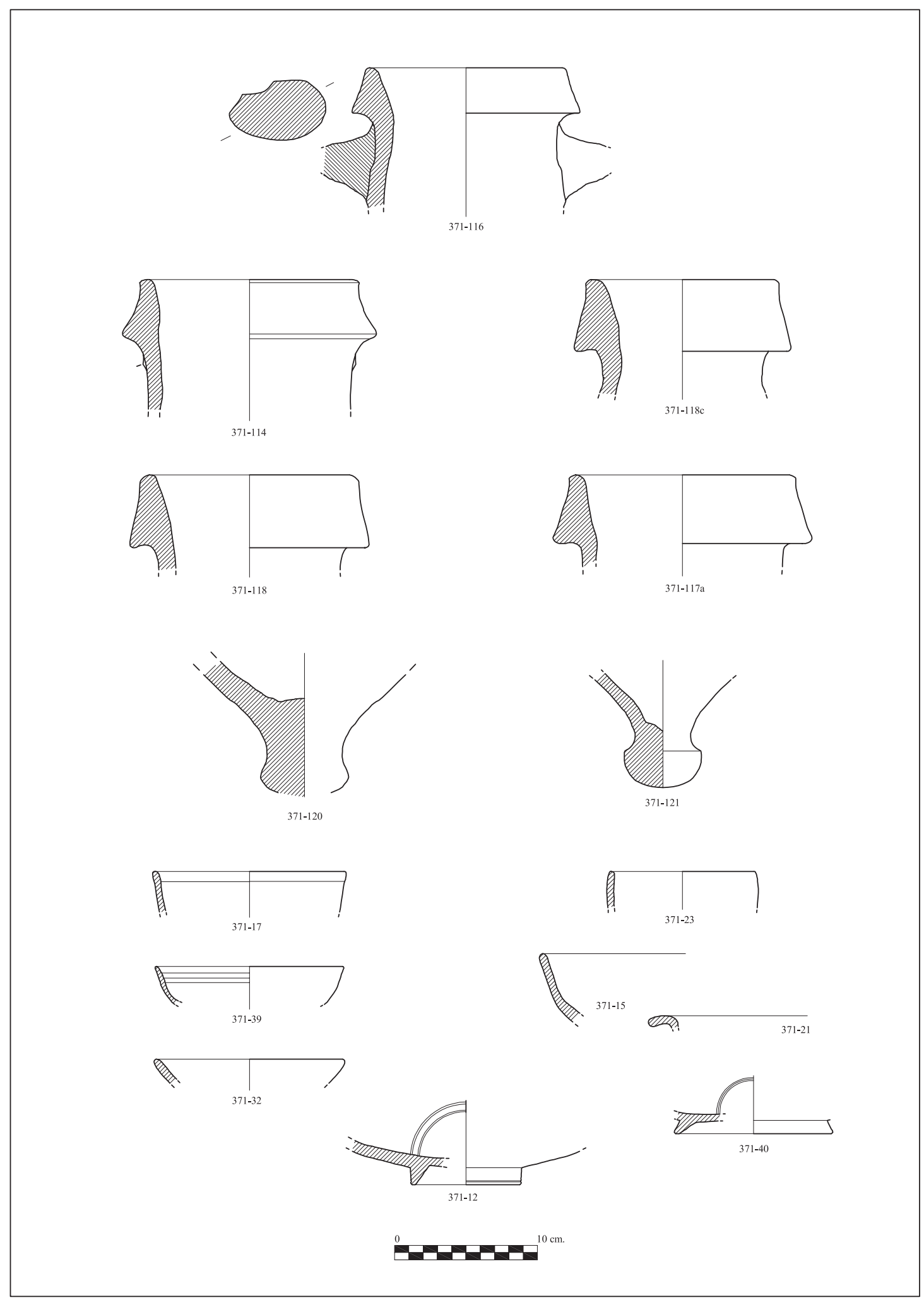

Lámina 9. UE 371 (cerámicas de importación). 
importaciones itálicas en un ambiente, por lo demás, en el que el mantenimiento de las técnicas edilicias y de gran parte del repertorio cerámico tradicional parece señalar como indígena o "turdetano".

Esta "primera ola" de importaciones itálicas se ve acompañada en Abades por la presencia minoritaria de material procedente de la bahía de Cádiz, entre el que destaca un ánfora salazonera del tipo 9.1.1.1 (Lám. 8: 371-119), habitual junto a las Dressel 1A en contextos de la segunda mitad del siglo II a.C. (Ramón 1995: 227), como los campamentos de Numancia o los niveles fundacionales de Valencia. De procedencia gaditana o de influencia púnica gaditana son igualmente dos piezas en cerámica común: una jarra monoansada (GDR. 10.2.) y una cazuela de borde ranurado (GDR. 11.1.1). La primera forma parece haber surgido en la bahía de Cádiz como evolución de las imitaciones más antiguas de olpes griegos en torno a los años centrales del siglo III, perdurando su fabricación al menos hasta la mitad del II a.C. (Sáez 2005: 161), aunque es posible que continuara todavía produciéndose durante la segunda mitad de esta centuria. La segunda forma, aunque cuenta con precedentes más antiguos en la bahía de Cádiz, parece remontarse al siglo III a.C. como consecuencia de la recepción en la zona de influencias centromediterráneas e ibicencas (ibidem: 162-163). A partir del siglo I, este tipo de cazuelas de tradición gardirita fue sustituido en la bahía de Cádiz y en el valle del Guadalquivir por cazuelas itálicas de borde bífido de la forma Vegas 14 .

Entre los contenedores de producción local destacan, por su frecuencia, las ánforas de la forma D de Pellicer. Como ya advertimos más arriba su producción debió iniciarse a finales del siglo IV o principios del III a.C. en la trascosta gaditana, si bien pronto parece extenderse por el Bajo Guadalquivir, la costa atlántica andaluza y Portugal (Arruda 2001). En Abades esta forma no aparecerá hasta mediados del siglo II a.C. (UE 380), aunque su presencia sí es habitual en otros sectores de la ciudad, al menos desde inicios de la centuria anterior (García y González 2007: 555). En nuestro caso se trata de ejemplares muy evolucionados, en los que puede apreciarse el progresivo estrechamiento y simplificación de los bordes (Pellicer 1982: 390), que en los siglos II y I a.C. apenas se diferencian ya del cuello (Lám. 7: 372-37).

Por lo que se refiere a la cerámica común, las producciones locales mantienen la tendencia a la simplificación formal y decorativa que veníamos advirtiendo en los siglos anteriores. Urnas, lebrillos, cuencos y platos continúan conformando el repertorio básico en los contextos domésticos del siglo II y durante la primera mitad del siglo I a.C. Desde el punto de vista técnico se observa ya un absoluto predominio de la cocción oxidante, con pastas muy depuradas y desgrasante homogéneo, mientras que la decoración pintada prácticamente ha desaparecido en las formas más comunes. La única excepción la tenemos en algunos lebrillos y urnas, que pueden ir decorados al interior o al exterior, respectivamente, con trazos irregulares y paralelos de tonos rojizos o motivos más complejos, como líneas onduladas, flameados, etc. Responden a un proceso de "barroquización" de la cerámica pintada que afecta principalmente a las formas de gran formato, probablemente como resultado de la pujanza que adquiere en estos momentos la vajilla ibérica en la Alta Andalucía y Levante, cuya distribución traspasa ya hacia occidente la cuenca del Genil. Por lo demás, los cuencoslucerna, vasos de perfil en S y las urnas gobulares con asas de orejeta siguen apareciendo con relativa frecuencia en los niveles republicanos, aunque tampoco podemos descartar su presencia en momentos posteriores al cambio de era.

Resulta llamativo el carácter conservador de los repertorios domésticos documentados en el corte $15 \mathrm{~A}$ de Abades, donde predomina claramente la cerámica de tradición local, frente a lo observado en otros sectores de la antigua ciudad republicana, como puede ser el caso de la excavación llevada a cabo en el número 7 de la calle Argote de Molina (Campos 1986). Aquí el tránsito del siglo II al I a.C. está representado por un repertorio en el que las cerámicas campanienses y las comunes itálicas permiten rastrear unas formas de consumo que, con carácter general, pueden considerarse como romanas o claramente romanizadas, mientras el registro cerámico de Abades, a unos escasos doscientos metros, sólo incorpora producciones relacionadas única o fundamentalmente con el consumo de vino.

El leve "decalage" cronológico entre ambos contextos introduce algunas dudas acerca de si estamos ante una diferenciación que haya que atribuir causas de tipo étnico o más bien son cronológicas. Aunque es cierto que el repertorio de la cerámica común itálica importada en Hispania se incrementa notablemente a partir del tránsito entre los siglos II y I, no lo es menos que ya desde principios del siglo II a.C. las ollas de borde bífido, los morteros campanos o las formas más antiguas de platos de engobe rojo de tipo pompeyano, formas frecuentes en Argote de Molina, llegaban en cierta cantidad a la Península (Aguarod 1991: 412) en los mismos barcos que transportaban las ánforas vinarias o la cerámica campana. Esto puede constituir un indicio de que estamos ante desarrollos que se justifican por causas diferentes a la simple disponibilidad de las diversas especies cerámicas. En tal caso, sería la adscripción cultural de los "usuarios" de la vajilla cerámica el factor principal 
que justificaría la diversa composición de los menajes. A ello, habría que unir la distinta funcionalidad de los espacios en los que las cerámicas en cuestión fueron amortizadas, pues la entidad de las edificaciones de sillares de Argote y su contextualización espacial difieren sustancialmente de la de las estructuras de Abades y permiten proponer un carácter público para las primeras, frente a la función eminentemente doméstica de las segundas.

Sólo a partir de la segunda mitad del siglo I a.C. se observa en Abades, en el corte 18A por ejemplo, la aparición de formas itálicas de cocina que suponen una paulatina sustitución de las formas herederas de la matriz orientalizante por nuevos tipos de origen itálico o derivados de éstos; un fenómeno que, ahora con más claridad, responde a la consolidación de los nuevos hábitos alimenticios y nuevas formas de cocinar, como resultado del impacto romanizador. Este cambio acompaña en Abades a una transformación clara tanto de los materiales empleados en las construcciones (signinum, ladrillo, etc.) como de las propias técnicas constructivas, de tal manera que podría considerarse que tanto los repertorios cerámicos como la edilicia privada apuntan en este caso hacia una clara romanización de las pautas culturales de los "usuarios" de las mismas. Un proceso identitario de asimilación que sólo en los últimos años estamos empezando a valorar gracias a un conocimiento mucho más profundo de la documentación material (Chaves y otros 2006).

\section{DINÁMICA CONSTRUCTIVAY Y CARACTERIZACIÓN CULTURAL}

El registro estratigráfico documentado evidencia una clara continuidad espacial, de lo que deducimos una continuidad residencial de varios siglos. Se individualizan 4 episodios constructivos hasta el siglo I a.C. Estos episodios se inician siempre con la destrucción y colmatación de las estructuras correspondientes a la fase anterior, que se construyen a menudo siguiendo las mismas técnicas, orientación y alineaciones establecidas en la fase previa. La cronología aportada por el exhaustivo análisis cerámico permite concluir que en cada generación, cada 40-50 años, el edificio cuyos restos se han documentado, era literalmente reedificado. Esto no quiere decir que las estructuras constructivas se mantuviesen inalteradas todo el tiempo de vida de cada edificio, pues en muchas de las fases establecidas se evidencian refacciones y reformas que afectaron sobre todo a las pavimentaciones.

Este panorama constructivo en Abades en nada difiere del conocido para otros yacimientos "turdetanos" del Bajo Guadalquivir. Los muros presentan base de mampostería irregular y alzados en adobe enlucidos de cal. Los pavimentos consisten habitualmente en capas de arcilla también encaladas. En los decenios finales del siglo II a.C. se constata el empleo de sistemas nuevos de pavimentación que pueden interpretarse como consecuencia de un cambio de funcionalidad del espacio mejor que como un testimonio más o menos directo de cambio o asimilación cultural. En la Estructura 5, en efecto, el pavimento original de cal enlucido en rojo fue sustituido en un segundo momento de vida del edificio por un encachado de fragmentos cerámicos alternados en algunas zonas con piedras calizas. Esta solución constructiva parece adecuada para la pavimentación de áreas abiertas, como "patios", o de espacios domésticos semiabiertos de función imprecisa. Los restos de un "banco" de mampostería de 25 x 50 $\mathrm{cm}$. (UE 368) que en un sector de la estancia servía de límite entre el encachado cerámico y las losas pueden tal vez considerase la base de un "pie de amigo" que actuara como sostén de una cubrición parcial y de escasa entidad constructiva.

El suelo de guijarros que constituye la pavimentación de la estructura superpuesta a la anterior (Estructura 6) indica que este espacio cumplió una función similar a la que había tenido en la Estructura 5. En este momento (fines del siglo I a.C.), la edilicia en ladrillo de la cimentación y los alzados de los muros constituye una novedad con respecto a lo anterior, indicando la asimilación de formas constructivas completamente ajenas a la tradición regional, asimilación que culminará finalmente con la sustitución del suelo de guijarros de la estancia por un pavimento de sigininum.

El empleo en la Bética del ladrillo como material constructivo en alzados ha sido considerado habitualmente un fenómeno característico de momentos imperiales avanzados, teniéndose su uso generalizado como un índice de los procesos de renovación urbanística ligados al fenómeno de la municipalización flavia (Roldán 1999: 180). Sin que esto deje de ser cierto en cuanto a la intensidad del uso, no es menos verdad que las evidencias de empleo del ladrillo con fines constructivos en la propia ciudad de Sevilla se remontan, en el estado actual de la investigación, al menos al período julio-claudio temprano. En el solar de la plaza de la Encarnación, los contextos correspondientes a la primera fase de ocupación de este sector urbano, cuya construcción se data entre los años 20 y 40 d.C. (Amores y González: 2006), el aparejo de ladrillo es usado habitualmente en los muros de división interna de los espacios excavados, mientras que en las fachadas se emplea aparejo de piedra de distinto tipo. La edilicia de 
estos muros es similar a la que se documenta en Abades 41-43, tratándose aparentemente también aquí de divisiones internas del espacio edificado que presentan pequeñas zarpas de cimentación también en ladrillos. Las pavimentaciones de las fases tempranas de la Encarnación no se han detectado con claridad, pero los restos conservados de la preparación de los suelos sugieren en algunas zonas, como en Abades, el empleo de pavimentos de signinum. Debe señalarse que en el caso de la Encarnación, la funcionalidad de estas primeras estructuras excavadas no es doméstica, sino "artesanal", lo que no invalida la comparación entre ambos lugares a efectos de edilicia y concepto constructivo.

La estratigrafía de Abades documenta, pues, un uso temprano del ladrillo en la ciudad y la sustitución progresiva de los muros de tapial tradicionales de la "edilicia turdetana". La introducción en la Ulterior del ladrillo como elemento de construcción se ha interpretado (Chic y García 2004: 311) como un indicio más del proceso de racionalización y geometrización del espacio introducido por el proceso de colonización cesariano, cuya difusión social se llevó a cabo incluso con tintes propagandísticos como los que se adivinan tras los sellos del legado propretor M. Petrucidius (Chic y García 2004: 311) sobre ladrillos fabricados en Carteia y distribuidos, y no es una casualidad, en las ciudades principales de la Provincia (Carteia, Asta Regia, Ilipa, Italica). Este proceso se completó a nivel práctico con disposiciones como la recogida en la ley de Osuna (Urso), colonia Julia, que obligaba a instalar extramuros las figlinae teglariae de cierto tamaño (cap. 76), lo que habla del control administrativo de las actividades productivas de interés edilicio, pero también de la voluntad de ordenar con criterios funcionales los espacios urbanos.

El alfar del Parlamento de Andalucía en Sevilla (Tabales 2003) muestra ya desde la mitad del siglo I d.C. la fabricación habitual de ladrillos y tégulas con destino a la construcción (García Vargas 2003) Los mismos hornos del alfar emplean el ladrillo como elemento de sustentación de las bóvedas, mientras que las piletas de decantación de arcilla son realizadas también en opus testaceum (Chic y García 2004).

Aunque no puede considerarse como un fenómeno que afecte de forma simultánea a todas las localidades de la Provincia, lo cierto es que las formas constructivas en la segunda mitad del siglo I a.C. constituyen un índice de romanización tan expresivo como el repertorio cerámico de producción local, que comenzó mucho antes a desarrollar formas romanas o claramente romanizadas en las zonas económicamente progresivas de la región (García Vargas 1996).

\section{BIBLIOGRAFÍA:}

ADROHER AROUX, A. M. y LÓPEZ MARCOS, A. (2000): "Contextos de barniz negro en la Alta Andalucía entre los siglos II y I A.C.", Taula Rotona: La ceràmica de vernis negre dels segles II $i$ I aC: centres productors mediterranis i cemercialització a la Península Ibèrica: 149-176. Mataró.

AGUAROD, C. (1991): Cerámica romana importada de cocina en la Tarraconense. Zaragoza.

AMORES CARREDANO, F. y GONZÁLEZ ACUÑA, D. (2006): Memoria preliminar de la actividad arqueológica preventiva "Proyecto de emergencia Plaza de la Encarnación (Sevilla). VI Fase de intervención arqueológica”. Delegación Provincial de la Consejería de Cultura, Junta de Andalucía, documento interno.

AQUILUÉ, X.; GARCÍA, J. y GUITART, J. (2000): "Conclusions", Taula Rotona: La ceràmica de vernis negre dels segles II i I aC: centres productors mediterranis i cemercialització a la Península Ibèrica: 395-409. Mataró.

AQUILUÉ, X.; CASTANYER, P.; SANTOS, M. y TREMOLEDA, J. (2000): "Les ceràmiques de vernís negre dels segles II i I aC a Empúries, l'Escala, Alt Empordà", Taula Rotona: La ceràmica de vernis negre dels segles II i I aC: centres productors mediterranis i cemercialització a la Península Ibèrica: 31-58. Mataró.

ARRUDA, A.M. (2001): "Importações púnicas no Algarve: cronología e significado", Os punicos no Extremo Occidente. Actas do Coloquio Internacional: 69-98. Lisboa.

BANDERA, Ma.L. y FERRER, E. (2002): “Secuencia estratigráfica tartesia y turdetana de Vico (Marchena, Sevilla)", Homenaje al Profesor Pellicer. Spal 11: 121-149. Sevilla. http://dx.doi. org/10.12795/spal.2002.i11.06

BELÉN, M. y FERNÁNDEZ-MIRANDA, M. (1978): "La Tiñosa (Lepe, Huelva)", Huelva Arqueológica IV: 197-297.

BENDALA GALÁN, M. (1976): La necrópolis romana de Carmona (Sevilla). Sevilla.

CAMPOS CARRASCO, J.M. (1986). Excavaciones arqueológicas en la ciudad de Sevilla. El origen Prerromano y la Hispalis Romana. Sevilla.

CAMPOS, J.; VERA, M. y MONEO, Ma.T. (1988): Protohistoria de la ciudad de Sevilla. El corte estratigráfico de San Isidoro 85-6, Monografías de Arqueología Andaluza 1. Sevilla.

CARRETERO POBLETE, P. (2004): "Las producciones cerámicas de ánforas tipo “Campamentos Numantinos" y su origen en San Fernando (Cádiz): los 
hornos de Pery Junquera", Actas del Congreso Internacional FIGLINAE BAETICAE. Talleres alfareros y producciones cerámicas en la Bética romana (ss. II a.C. - VII d.C.). BAR International Series 1266: 427-440. Oxford.

- (2005): "Difusión de ánforas tipo "Tiñosa" en Algarve (Portugal) y la comercialización de productos agrícolas púnico-turdetanos entre los siglos V y III a.C.", Actas del II Encontro de Arqueologia do Algarbe. XELB 5, Silves.

- (e.p.): "Las villas agrícolas púnico-turdetanas de la campiña gaditana (Cádiz-España)", II Coloquio del CEFYP (Adra, 2004).

CARRIAZO, J. de Mata y RADDATZ, K. (1960): "Primicias de un corte estratigráfico en Carmona", Archivo Hispalense 103-104: 12-49.

CHAVES, F.; GARCÍA, F.J. y FERRER, E. (2006): "Relaciones interétnicas e identidades culturales en Turdetania (siglos II a.C.-I d.C.)", L'Africa Romana. Atti del XVI Convengo di Studio, vol. 2: 813827. Sassari.

CHIC GARCÍA, G. y GARCÍA VARGAS, E. (2004): "Alfares y producciones cerámicas en la provincia de Sevilla. Balance y perspectivas", Actas del Congreso Internacional FIGLINAE BAETICAE. Talleres alfareros y producciones cerámicas en la Bética romana (ss. II a.C. - VII d.C.). BAR International Series 1266: 279-348. Oxford.

CORZO, R. (1991): "Las termas, la ciudad y el río de Sevilla en la Antigüedad. Excavaciones en la calle de Abades", Temas de Estética y Arte V: 68-96.

DOMÍNGUEZ, M.C.; CABRERA, P. y FERNÁNDEZ, F. (1988): "Cerro de la Cabeza (Santiponce, Sevilla)", NAH 30: 119-183.

ESCACENA CARRASCO, J.L. (1987): Cerámicas a torno pintadas andaluzas de la segunda Edad del Hierro (Tesis Doctoral microfilmada). Cádiz.

- (1992): "Indicadores étnicos en la Andalucía prerromana”, Spal 1: 321-343. http://dx.doi.org/10.12795/ spal.1992.11.16

FERNÁNDEZ, F.; CHASCO, R. y OLIVA, D. (1979): "Excavaciones en El Cerro Macareno. La Rinconada. Sevilla (Cortes E-F-G. Campaña 1974)", NAH 7: 9-93.

FERRER, E. y GARCÍA, F.J. (2002): “Turdetania y turdetanos: contribuciones a una problemática historiográfica y arqueológica", Colonizadores e indígenas en la Península Ibérica. Mainake XXIX: 133-151. Málaga.

FERRER, E; GARCÍA, F.J. y GONZÁLEZ, D. (e.p.): "El comercio púnico en Spal", VI Congreso de Estudos Fenicios e Punicos (Lisboa 2005).
FRUTOS, G. de y MUÑOZ, A. (1996): "La industria pesquera y conservera púnico-gaditana: balance de la investigación. Nuevas perspectivas", Spal 5: 133165. http://dx.doi.org/10.12795/spal.1996.i5.07

GARCÍA FERNÁNDEZ, F.J. (2002): "Turdetania, turdetanos y cultura turdetana", Quaderni Ticinesi di Numismatica e Antichità Classiche XXXI: 191-202.

- (2007): "Etnología y etnias de la Turdetania en época prerromana", CUPAUAM 33: 117-143.

GARCÍA FERNÁNDEZ, F.J. y GONZÁLEZ ACUÑA, D. (2007): "Secuencias estratigráficas y contextos culturales de la Sevilla prerromana", Actas del V Congreso de Historia de Carmona. Los orígenes de la ciudad: la Carmona Protohistórica: 525-566. Carmona.

GARCÍA VARGAS, E. (1996): “La producción anfórica en la bahía de Cádiz durante la República como índice de romanización", Habis 27: 49-62.

- (2003): "Las producciones de la figlina: materiales de construcción", Arqueología y Rehabilitación en el Parlamento de Andalucía. Investigaciones Arqueológicas en el Hospital de las Cinco Llagas de Sevilla: 197-199. Sevilla.

GARCÍA VARGAS, E.; MORA, M. y FERRER, E. (1989): "Estudios sobre cerámicas ibéricas andaluzas: Montemolín (Marchena, Sevilla)", Habis 20: 217-243.

JIMÉNEZ SANCHO, A. (2001): Informe provisional de la intervención arqueológica de urgencia en $\mathrm{Ca}$ lle Abades 41-43 (Sevilla), 2001. Delegación Provincial de la Consejería de Cultura, Junta de Andalucía, documento interno.

JIMÉNEZ SANCHO, A. (2002) "Excavación en c/ Abades 41-43 (Sevilla); del siglo III a.C. al siglo IV", Romula 1: 125-150.

JIMÉNEZ, A.M" y GARCÍA, F.J. (2006): “In vino humanitas (y II): vino y cultura en la Turdetania prerromana", Habis 37: 125-144.

KEAY, S. (1992): “The 'Romanisation' of Turdetania”, Oxford Journal of Archaeology 11 (3): 275-315.

LAMBOGLIA, N. (1964): "La campagna 1963 sul relitto di Punta Scaletta all'isola di Giannutri”, $R S L$ XXX: 229-257.

LUZÓN NOGUÉ, J.Ma . (1973): Excavaciones en Itálica. Estratigrafía en el Pajar de Artillo. EAE 78. Madrid.

MARÍN JORDÁ, C. y RIBERA i LACOMBA, A. (2000): "Las cerámicas de barniz negro de Valentia", Taula Rotona: La ceràmica de vernis negre dels segles II i I aC: centres productors mediterranis i cemercialització a la Península Ibèrica: 91105. Mataró. 
MOREL, J. - P. (1981): Céramique campanienne. Les formes (2 vols). Roma.

MUÑOZ VICENTE, A. (1987): "Las ánforas prerromanas de Cádiz (informe preliminar)”, $A A A / 1985$, vol. II: 471-478.

NIVEAU DE VILLEDARY Y MARIÑAS, A.M ${ }^{\mathrm{a}}$. (2002): "Las ánforas turdetanas del tipo PellicerD. Ensayo de clasificación", Homenaje al Profesor Pellicer. Spal 11: 233-252. Sevilla. http://dx.doi. org/10.12795/spal.2002.i11.12

- (2003): Cerámicas gaditanas "tipo Kuass". Madrid.

PELLICER CATALÁN, M. (1978): “Tipología y cronología de las ánforas prerromanas del Guadalquivir según el Cerro Macareno (Sevilla)", Habis 9: 365-400.

- (1982): "Las cerámicas del mundo fenicio en el Bajo Guadalquivir: evolución y cronología según el Cerro Macareno (Sevilla)", Phöinizier im Westen. Madrider Beiträge 8: 371-406. Maguncia.

PELLICER, M. - ESCACENA, J.L. - BENDALA, M. (1983): El Cerro Macareno. EAE 124. Madrid.

PELLICER, M. y AMORES, F. (1985): "Protohistoria de Carmona. Los cortes estratigráficos CA-80/A y CA-80/B", NAH 22: 55-189.

PEREIRA SIESO, J. (1989): “La cerámica ibérica de la cuenca del Guadalquivir, II. Conclusiones", TP 46: 149-159.

PUPPO, L. (1995): Le coppe megaresi in Italia, St Arch 78. Roma.

PRINCIPAL, J. (2000): "Vajilla de barniz negro de los campamentos del cerco numantino (Garray, Soria)", Taula Rotona: La ceràmica de vernis negre dels segles II i I aC: centres productors mediterranis i cemercialització a la Península Ibèrica: 269-279. Mataró.

- (2005): "La cerámica del círculo de la campaniense B", Introducción al estudio de la cerámica romana. Una breve guía de referencia: 47-61. Málaga.

RAMÓN TORRES, J. (1991): Las ánforas púnicas de Ibiza. Ibiza.

- (1995): Las ánforas fenicio-púnicas del Mediterráneo central y occidental. Barcelona.

ROCA ROUMENS, M. y FERNÁNDEZ GARCÍA, $\mathrm{M}^{\mathrm{a}}$.I. (coords.) (2005): Introducción al estudio de la cerámica romana. Una breve guía de referencia. Monográficos de CVDAS, $\mathrm{n}^{\circ} 1$. Málaga.

RODERO, A. (1991): “Las ánforas del Mediterráneo Occidental en Andalucía", TP 48: 275-298.

ROLDÁN GÓMEZ, L. (1999): “Arquitectura pública en las ciudades de la Bética: el uso del opus testaceum", El ladrillo y sus derivados en época romana. Monografias de Arquitectura Romana 4: 179-204. Madrid.

RUIZ MATA, D. (1987): "La formación de la cultura turdetana en la Bahía de Cádiz a través del Castillo de Doña Blanca", Iberos. Actas de las I Jornadas sobre el Mundo Ibérico: 299-314. Jaén.

SÁEZ ROMERO, A.M. (2005): “Aproximación a la tipología de la cerámica común púnico-gadirita de los ss. III-II", Spal 14: 145-177. http://dx.doi. org/10.12795/spal.2005.i14.06

SÁEZ, A.M. - DÍAZ, J.J. - MONTERO, R. (2004): "Acerca de un tipo de ánfora salazonera púnico-gadirita", Habis 35: 109-133.

TABALES RODRÍGUEZ, M. A. (2003): “El complejo alfarero localizado bajo el Parlamento de Andalucía", Arqueología y Rehabilitación en el Parlamento de Andalucía. Investigaciones Arqueológicas en el Hospital de las Cinco Llagas de Sevilla: 139-162. Sevilla.

VIVAR LOMBARTE, G. (2005): "La cerámica campaniense A", Introducción al estudio de la cerámica romana. Una breve guía de referencia: 2345. Málaga. 